Review

\title{
Lemongrass essential oil components with antimicrobial and anticancer activities
}

\author{
Mohammad Mukarram 1,2, ${ }^{*}$, Sadaf Choudhary ${ }^{1}$, Mo Ahamad Khan ${ }^{3}$, Palmiro Poltronieri ${ }^{4, *}$, M. Masroor A. Khan \\ 1 , Jamin Ali ${ }^{5}$, Daniel Kurjak ${ }^{2}$ and Mohd Shahid ${ }^{6}$
}

1 Advance Plant Physiology Section, Department of Botany, Aligarh Muslim University, Aligarh 202002, India; mdmukarram007@gmail.com (M.M.); sadafchoudhary92@gmail.com (S.C.); masruur@gmail.com (M.M.A.K.)

2 Department of Integrated Forest and Landscape Protection, Faculty of Forestry, Technical University in Zvolen, T. G. Masaryka 24, 96001, Zvolen, Slovakia; kurjakd@gmail.com (D.K.)

3 Department of Microbiology, Jawaharlal Nehru Medical College, Aligarh Muslim University, Aligarh 202002, India; ahmadk065@gmail.com (M.A.K.)

4 Institute of Sciences of Food Productions, ISPA-CNR, National Research Council of Italy, via Monteroni km 7, 73100 Lecce, Italy; palmiro.poltronieri@ispa.cnr.it (P.P.)

5 Centre for Applied Entomology \& Parasitology, School of Life Sciences, Keele University, United Kingdom; j.ali@keele.ac.uk (J.A.)

6 Department of Microbiology, Immunology \& Infectious Diseases, College of Medicine \& Medical Sciences, Arabian Gulf University, Kingdom of Bahrain; drmohdshahid12347@yahoo.co.nz (M.S.)

* Correspondence: palmiro.poltronieri@ispa.cnr.it (P.P.); mdmukarram007@gmail.com (M.M.)

\begin{abstract}
The prominent cultivation of lemongrass relies on the pharmacological incentives of its essential oil. The lemongrass essential oil (LEO) has a significant amount of citral (mixture of geranial and neral), isoneral, isogeranial, geraniol, geranyl acetate, citronellal, citronellol, germacrene-D, and elemol in addition to numerous other bioactive compounds. These components confer various medicinal activities to LEO including antifungal, antibacterial, antiviral, anticancer, and antioxidant properties. These attributes are commercially exploited in pharmaceutical, cosmetics, and food preservations industries. Furthermore, the employment of LEO in the treatment of cancer opens a new vista in the field of therapeutics. Although different LEO components have shown promising anticancer activities in vitro, these effects have not been assessed yet in humans. Further studies on the anticancer mechanisms exerted by lemongrass components are required. The present review intends to provide a timely discussion on the relevance of lemongrass extracts in cancer and health, and in food industry applications.
\end{abstract}

Keywords: anticancer, antimicrobial, antioxidants, cancer signalling, citral, Cymbopogon, essential oil

\section{Lemongrass}

The lemongrass is a fast-growing $C_{4}$ perennial sedge from the grass family Poaceae and is commonly known as East Indian or Malabar grass. Lemongrass plants are primarily cultivated for the essential oils. These aromatic grasses are of great commercial interest due to their wide applications in different areas such as the food, pharmaceutical, and cosmetic industries. The plant propagates through seed and slips and has thin and lanceolate leaves that appear to emerge directly from the soil without any stem [1]. Although lemongrass cultivation is cosmopolitan, India has a monopoly over its production and export [2,3]. The lemongrass is also called Cochin grass since $90 \%$ of its global export is organised from Cochin port, India [4]. The lemongrass plant has extensive potential as food and fodder given its richness in vitamin A, C, E, folate, niacin, and riboflavin, protein, antioxidants, and mineral nutrients such as $\mathrm{N}(0.74 \%), \mathrm{P}(0.07 \%), \mathrm{K}$ $(2.12 \%), S(0.19 \%), \mathrm{Mg}(0.15 \%), \mathrm{Ca}(0.36 \%), \mathrm{Zn}(35.51 \mathrm{ppm}), \mathrm{Mn}(155.82 \%), \mathrm{Fe}(126.73 \%)$, 
and $\mathrm{Cu}(56.64 \mathrm{ppm})[5,6]$. Figure 1 illustrates the morphological attributes of lemongrass plants focusing on the characteristics of glandular trichomes and stomata.

Lemongrass cultivation is a rapidly growing economy. The major drive for lemongrass cultivation is its high industrial potential in the pharmaceutical, food, and cosmetics sectors. It is grown over an area of 16,000 ha on a global scale that produces about $1000 \mathrm{t}$ of lemongrass essential oil (LEO) each year [7]. Out of this, India accounts for one-fourth of total production and area cropped worldwide [8]. Lemongrass cultivation can provide a net profit of about 300 USD per year per hectare [9]. A recent report by Profshare Market Research pins the global lemongrass oil market at 247 million dollars in 2019 and expects to grow to 421 million dollars in 2027 at a compound annual growth rate of $7 \%$. Additionally, the lemongrass export of India has risen more than $1250 \%$ from 2001 to 2020 which solidifies its demand and importance (source: The Directorate General of Commercial Intelligence and Statistics). Moreover, the size of the essential oil market is estimated by numerous market research firms. One such study by Facts and Factors estimates its size to be 7 billion dollars which are expected to double by 2027. Given the growing consumer demand and global market for essential oil, few recent reports have suggested various sustainable approaches for enhancing lemongrass production even further [3].
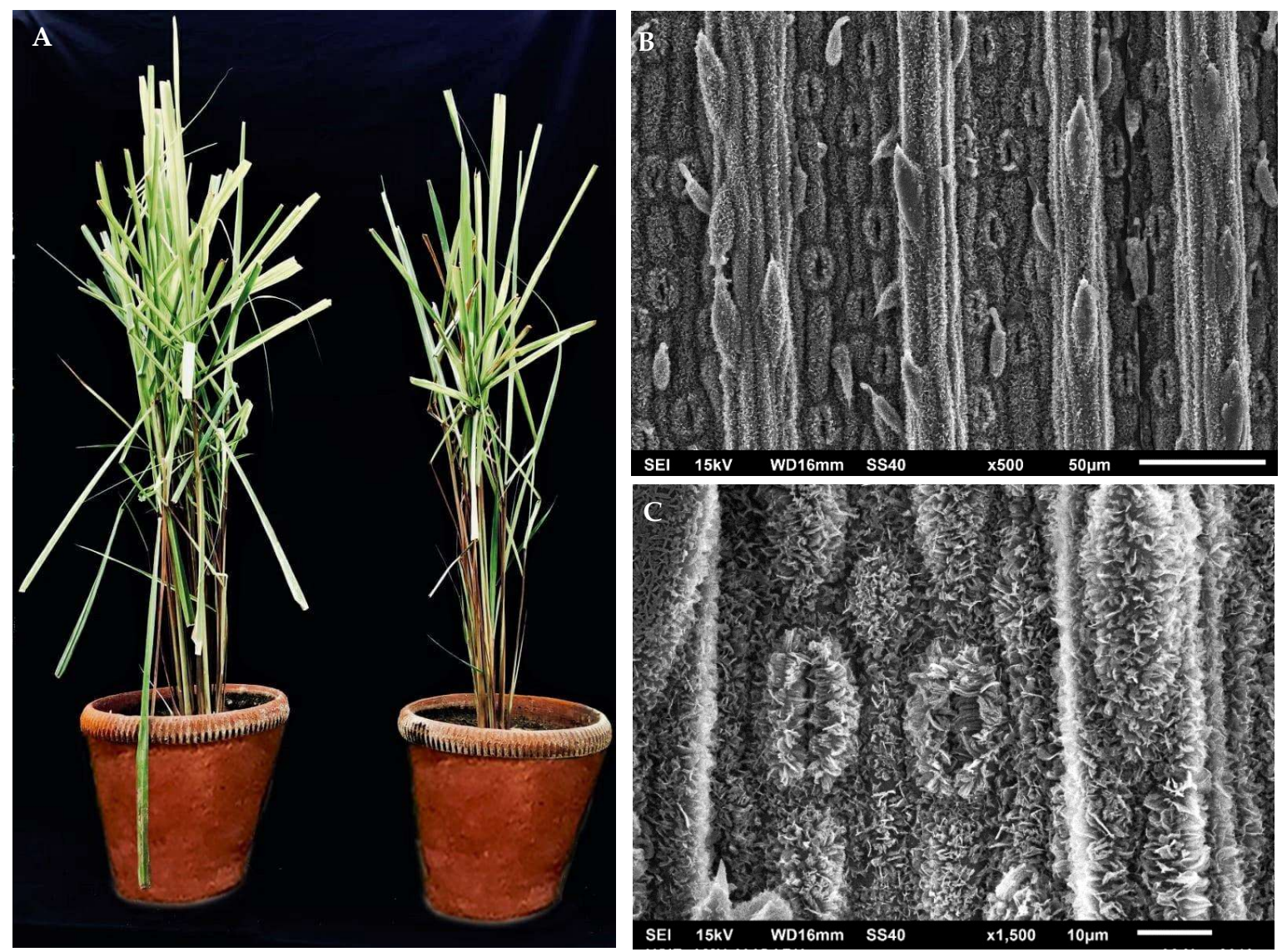

Figure 1. Morphological and anatomical profile of the lemongrass plants. The morphological representation of 150-days-old healthy lemongrass plants (A). Scanning electron microscopy (SEM) analysis of lemongrass leaf visualising glandular trichomes at $\times 500$ magnification (B) and stomatal characteristics at $\times 1500$ magnification (C).

\section{LEO: Biosynthesis and chemical composition}

Lemongrass oil is a cocktail of various terpenes and terpenoids, out of which the major components belong to cyclic and acyclic monoterpenes. The monoterpenes are 
derived from geranyl diphosphate (GPP). The GPP is a fusion component of isopentenyl diphosphate (IPP) and its allylic isomer dimethylallyl diphosphate (DMAPP). The IPP is a precursor of all the terpenes and terpenoids. Earlier it was widely accepted that plants produce IPP through a cytoplasmic mevalonate (MVA) pathway. However, empirical studies reveal that a newly discovered methylerythritol phosphate (MEP) pathway for monoterpenes biosynthesis is more dominant in lemongrass species [10]. The plastidic MEP pathway begins with the reaction of pyruvate with thiamine diphosphate (TPP) that yields hydroxyethyl-TPP. Hydroxyethyl-TPP upon reacting with glyceraldehyde 3phosphate (GAP) releases 1-deoxy-D-xylulose 5-phosphate (DXP). Subsequently, DXP rearranges and reduces to MEP that is further phosphorylated and ultimately generates IPP.

On the other hand, the MVA pathway involves the condensation of three acetyl-CoA molecules into 3-hydroxymethylglutaryl-CoA (HMG-CoA). The HMG-CoA is reduced to MVA and the subsequent steps of MVA phosphorylation produce IPP. The IPP produced from MEP/MVA pathway reacts with DMAPP to yield GPP which subsequently forms geraniol in lemongrass. Geraniol through different reversible reactions produces all the major components of lemongrass oil [11]. (Figure 2)

LEO is produced only in young and rapidly growing lemongrass leaves and floral tops and is stored in specialized parenchymal oil cells between vascular bundles proximal to non-photosynthetic tissue [12]. The amount of lemongrass oil is about $1-2 \%$ of its total dry weight [13]. However, various drying methods can produce different content and quality of LEO [14]. The LEO components can be categorised into terpenes, terpenoids, flavonoids, phenols, phenolics, tannins, fatty alcohols, and steroids. The genus Cymbopogon comprises about 180 species differing in their essential oil content and composition. The most common lemongrass species are C. citratus, C. flexuosus, C. winterianus, C. martinii, C. nardus, and C. refractus. The content of oil constituents may also vary with the extraction method, developmental stage, and the solvent used for extraction [15]. The major components in most lemongrass species include neral, isoneral, geranial, isogeranial, geraniol, geranyl acetate, citronellal, citronellol, germacrene-D, and elemol and make up about $60-80 \%$ of LEO. The remaining components also called minor components, comprise camphene, pinene, limonene, linalool, citronellyl acetate, elemene, and caryophyllene oxide [11]. The isomeric mixture of geranial and neral is known as citral and its content can be used as a quality marker for LEO [16]. This aldehyde monoterpene is the key active constituent $(<80 \%)$ of Cymbopogon flexuosus oil, making it an aldehyde-type grass. Alternatively, Cymbopogon martinii (Palmarosa) has more alcohol content (nerol and geraniol) than aldehydes (neral and geranial) and thus is called an alcohol type grass while Cymbopogon winterianus (Java citronella) is an intermediate type due to the moderate contents of aldehyde and alcohol in its essential oil [17]. (Figure 2) 


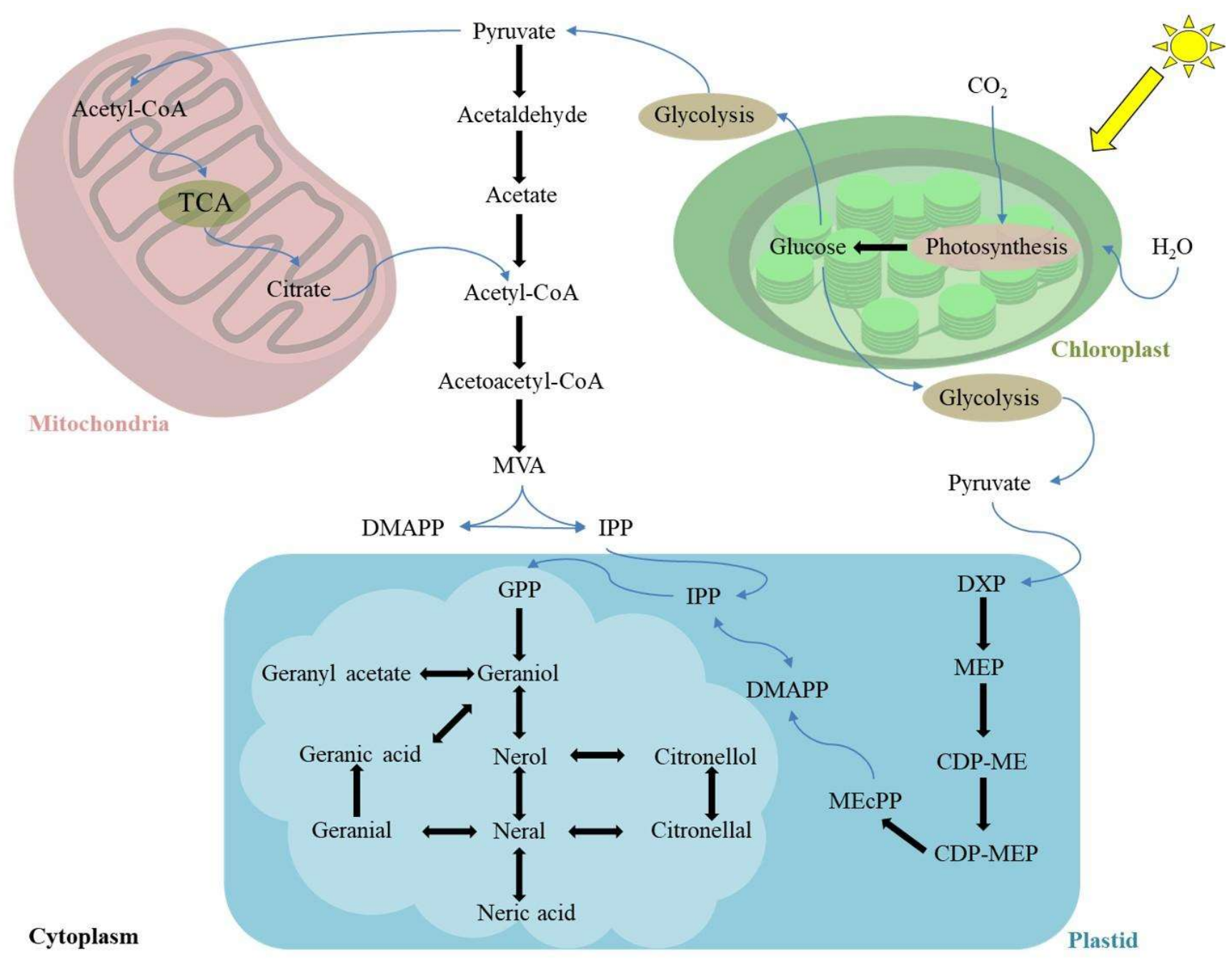

Figure 2. A mechanistic model for the biosynthesis of lemongrass essential oil and its crosstalk with other metabolic processes. Different cellular organelles work in tandem for oil production in lemongrass leaves. The lemongrass chloroplast like most of the other plants produces glucose through photosynthesis. The glucose undergoes glycolysis in the cytoplasm and yields pyruvate, a 2-carbon compound. The lemongrass uses the pyruvate as a substrate for the biosynthesis of isopentenyl diphosphate (IPP) units either through the cytoplasmic mevalonate (MVA) pathway or plastidic methylerythritol phosphate (MEP) pathway in their young and rapidly growing leaves. Alternatively, mitochondria can import pyruvate and yield citrate through the tricarboxylic acid (TCA) cycle. The citrate can transform into Acetyl-CoA and join the MVA pathway to yield IPP units. The IPP produced through both pathways is converted into geraniol mediated by geranyl diphosphate (GPP) in lemongrass plastids. The geraniol is considered as a precursor for essential oil biosynthesis in lemongrass and yields all the major components through multiple reversible and irreversible reactions. The plastidic bubble highlights these reactions along with their substrates. DMAPP, dimethylallyl diphosphate; DXP, 1-deoxy-D-xylulose-5-phosphate; MEP, 2-C methylerythritol 4-phosphate; CDP-ME, 4-diphosphocytidyl-2-Cmethyl-D-erythritol; CDP-MEP, 4-diphosphocytidyl-2-C-methyl-D-erythritol-2-phosphate; MEcPP, 2-C-methyl-D-erythritol 2,4cyclodiphosphate.

\section{LEO therapeutics}

Recent decades mark an exponential upsurge in establishing the bioactivities of lemongrass extract and essential oil. Feeding studies establish that LEO has antimicrobial, anticancer, anti-amoebic, anti-diarrhoeal, anti-filarial, antitussive, antiseptic, larvicidal, insecticidal, miticidal, ovicidal, acaricidal, analgesic, anesthetic, anti-inflammatory, antioxidant, antinociceptive, antihypertensive, anti-obesity, anxiolytic, and antimutagenicity potential, cardio-protective, anti-rheumatic, and hematological properties [7,17-29]. These bioactivities are the direct product of the individual and 
synergistic effect of different major and minor LEO components [11]. The LEO therapeutics is an emerging alternative for synthetic pharmaceuticals due to its naturality, biocompatibility, and inexpensiveness.

\subsection{Antimicrobial potential}

The lemongrass oil and extract are effective against a wide variety of disease-causing microbes [31]. Several studies have used LEO as an antibacterial [21,32,33], antifungal $[30,34]$, and antiviral $[21,35,36]$ agent. Similarly, lemongrass extract inhibited the growth of Bacillus cereus, Escherichia coli, Klebsiella pneumoniae, Candida albicans, and Staphylococcus aureus with different levels of susceptibility [37]. The EO components with different functional groups exhibit different levels of antimicrobial potential where phenols and aldehydes have the highest activities while esters and hydrocarbons have the least [38]. However, the antimicrobial activity of lemongrass is extensively attributed to the citral (aldehyde) present in its oil [26,39,40]. It is suggested low concentration of LEO inhibits microbial growth and development (bacteriostatic, fungistatic, and virustatic) while higher concentration renders irreversible destruction leading to microbial death (bactericidal, fungicidal, and virucidal) [41,42]. On a similar note, one study addressed LEO antimicrobial potential against 42 microorganisms, including 20 bacteria, 15 fungi, and 7 yeasts [43]. Furthermore, Singh et al. [41] studied 1114 strains of different microbes including molds, yeasts, and bacteria from 29 genera and 105 species, and circled out about 425 LEO sensitive microbial isolates.

\subsubsection{Antibacterial activity}

The antibacterial characteristic of LEO is well established [16,38,44-48]. It is suggested that LEO induces the destruction of bacterial biofilms and hinders further bacterial growth and development [49]. Furthermore, LEO components can destabilise the bonds between the lipid bilayer and neutralise the bacteria through membrane disintegration [50]. The LEO can confer structural changes as well in different bacteria. It was reported to cause complete disfiguration and distortion in the Pseudomonas spp. [51]. Furthermore, LEO blocks biofilm formation in bacterial colonies [52]. It can disrupt the cell membrane and inhibit cytoplasmic metabolism, making LEO effective against both gram-negative and gram-positive bacteria [32,47,53]. Multiple recent studies against MDR (multidrug-resistant) bacteria [54,55] showed that a low concentration of LEO retarded growth and biofilm formation while a higher concentration of LEO conferred complete elimination of Salmonella Heidelberg.

It is believed that the geranial and neral are responsible for the antibacterial activity of lemongrass oil. However, when a mixture of principal oil components and the whole EO were tested, the whole EO exhibited enhanced efficacy against bacteria [43]. This implies that minor components including limonene, linalool, and myrcene have specific as well as a synergistic mechanism with major components and can play a decisive role in augmenting oil effectivity $[51,56]$.

The bacteriostatic and bactericidal characteristics of LEO primarily depend on the bacteria and oil concentration [57,58]. However, several other factors such as oil composition, extraction method, plant developmental stage, and environmental variables including temperature can influence the oil's effectiveness. Therefore, lemongrass oils from different species might exhibit effects of different nature and intensity. Nevertheless, the host organism can also decide oil effectiveness to a certain extent depending on its morpho-physiological attributes [59]. Therefore, EOs react differently with gram-positive and gram-negative bacteria differently owing to their dissimilar cell wall structure $[57,60]$. 


\subsubsection{Antifungal activity}

Antifungal activity of LEO has been reported against multiple fungi [38,61-63]. Volatiles from lemongrass oil such as phenols, flavonoids, and flavones are effective against numerous fungal strains [64,65]. Helal et al. [66] reported that LEO caused plasma membrane disruption and disorganisation of mitochondria and resulted in $\mathrm{Ca}^{2+}, \mathrm{K}^{+}$, and $\mathrm{Mg}^{2+}$ leakage. The loss of ions can further affect signal transduction and fungal germination. Moreover, Alviano et al. [67] observed that LEO components induce cell size reduction and inhibit the spore germination in Candida albicans. LEO can directly act upon the fungal lipid bilayer owing to its readily volatile and lipophilic nature. It can form a charge-transfer complex with the lipid bilayer, destabilising membrane and inhibiting further membrane synthesis, and retards fungal spore formation and cellular respiration [68]. Boukhatem et al. [51] found that the vapour form of LEO inhibits mycotic growth and development more effectively than the liquid phase, probably because of the direct accumulation of the LEO vapours on fungal mycelium. It was also suggested that lemongrass oil induces ROS production in fungi and afflicts severe oxidative damage that leads to subsequent cellular death [30].

The LEO components including citral, geraniol, myrcene, limonene, and linalool have significant antifungal activity $[40,44,69]$. Geraniol increases the outward leakage rate of potassium ions, while citral damages the microtubules and exhibits cytotoxicity in fungi [25]. Linalool, a monoterpene alcohol, comprises numerous fungicidal properties [67]. It retards the overall development and propagation of different fungi through the respiratory restriction of their aerial mycelia [51]. Additionally, other aldehydes of LEO can confer antimycotic activity through cross-linkage reaction within the fungal membrane [51].

It was suggested that EOs can be used in the food preservation and packaging industry [70]. EOs can remain effective for a longer duration against fungal spore production, ensuring improved shelf life for food products [62,71]. Edible coating of EOs including LEO on stored fruits, meat, and dairy products discourages the fungal attack and food spoilage through restricting fungal growth and reproduction [72-76]. Moreover, different EOs have different antimicrobial mechanisms, and thus acquisition of resistance by microbes against the wide array of compounds in EOs is rare [77]. The edible coatings of EOs have increased antimicrobial potential over the free EOs due to their altered surface charge and amplified action on multiple target sites in the mycotic membrane [60]. This elongates edibility and maintains physicochemical qualities including taste and odour of such products [64,78].

\subsubsection{Antiviral activity}

In addition to fungi and bacteria, the LEO is equally effective against numerous viruses. The antiviral activity of lemongrass oil was tested against herpes simplex virus-I (HSV-I) [35] and murine norovirus (MNV) [79]. The studies demonstrated that $0.1 \%$ and $2 \%$ of LEO concentrations were potent enough to inhibit the replication of HSV-I and MNV, respectively. Furthermore, LEO can weaken the HIV transcription and virus reactivation by interfering with the Tat/TAR-RNA complex. As the Tat protein enhances the efficiency of viral transcription, LEO's interference with the Tat/TAR-RNA complex results in the downregulation of HIV activity [80]. The lemongrass volatiles were also able to cause more than $50 \%$ inhibition of the tobacco mosaic virus at $100 \mu \mathrm{g} / \mathrm{ml}$ concentration [42]. Human mastadenovirus (HAdV) causes numerous ailments such as respiratory infection, gastroenteritis, hepatitis, meningoencephalitis, pneumonia, and multiple others. Lemongrass extracts also induced cytotoxicity in the human lung adenocarcinoma cell line and kidney cell lines of the monkey and rendered antiviral activity against HAdV 
[81]. In the recent pandemic upsurge, the efficacy of LEO was suggested against influenza and coronaviruses SARS-CoV-2 as well, enhancing the relevance and importance of lemongrass oil even more [36,82].

\subsection{Antioxidant related effects}

Plant and animal cells produce various oxidative compounds such as $\mathrm{H}_{2} \mathrm{O}_{2}, \mathrm{O}_{2}^{-}$, and $\mathrm{OH}^{-}$, which can damage lipids, proteins, and DNA and can induce several health complications including cancer, aging, and neurological disorders in humans [24]. However, another group of compounds known as antioxidants has the potential to counter these effects [83]. Lemongrass possesses antioxidants that render protective measures against reactive species [84,85]. Lemongrass extracts have been reported to reduce reactive species concentration, lipid peroxidation, and decolourisation of 2,2-diphenyl-1-picrylhydrazyl $[86,87]$. Lemongrass extract can also buttress the endogenous antioxidant defence system in alveolar macrophages cells through augmenting the superoxide dismutase activity and glutathione formation [88]. Several plant extracts have been studied for their antioxidant beneficial properties. In particular, regulation of redox status in cells may affect the levels of methyl group donor S-adenosylmethionine (SAM). SAM is a cofactor for histone methyltransferases and DNA methyltransferases. A consumption of glutathione, as occurs during oxidative stress, with increase of its oxidised form, GSSG, may inhibit Sadenosylmethionine (SAM) synthetase, with a reduction of SAM synthesis [89] influencing the epigenetic modifications of proteins and DNA. Citral was shown to increase intracellular oxygen radicals while inhibition of glutathione synthesis increased citral anticancer effect [90]. Citral was shown to modulate oxidative stress preferentially in cancer cells and to induce the endoplasmic reticulum stress exerting thus an antiproliferative action [90]. Lemongrass has a competitive advantage over other synthetic antioxidants such as butylated hydroxytoluene since they can induce haemorrhages: in this optic, lemongrass oil is regarded 'safe' for human consumption [91]. This opens a new vista for lemongrass oil in food preservation and safety industries including meat, and dairy industries [51]. In the food industry, the oxidation of lipids is an important determinant of meat and dairy products. However, their highly rich nutritional profiles are prone to lipid peroxidation and quality deterioration. In this regard, coating such products with LEO minimises lipid peroxidation and increases their shelf life and quality [92]. Furthermore, the antioxidative nature of citral is exploited in animal skin cancer models [93]. Soares et al. [94] reported that LEO has high antioxidant activity compared to the methanolic crude extract of lemongrass. The antioxidant activity of LEO can further be enhanced through mixing it with other potent antioxidative agents. On this note, a mixture of LEO with Ocimum gratissimum, and Thymus vulgaris oil had enhanced effectiveness against Bipolaris oryzae and Alternaria alternata [95].

\subsection{Anticancer activity}

According to the World Health Organization (WHO), cancer caused an approximated 10 million deaths, or one in six deaths, in 2020. This situation is not going to be relieved, as there is an estimated increase of $45 \%$ in cancer mortality rate between 2008-2030. Among these, the most common types are breast cancer, lung cancer, colorectal cancer, prostate cancer, skin, and stomach cancer. The ongoing conventional chemotherapies, radiotherapy treatment, and surgeries have shown a large number of involuntary side effects due to insufficient knowledge of treatment specificity, and are not recommended for long-term usage [96].

Medicinal plants emerge as potential candidates in the cancer world and raise hopes for the scientific community. Scientists are constantly looking for natural sources to uncover 
the potential plant-based therapeutic agents having immense anticancer properties [97]. In this sense, the essential oil of lemongrass counts for its cytotoxicity on human cancer cells. Its active ingredients including geraniol, geranyl acetate, $\alpha$-bisabolol, and isointermedeol have individually been found to impart cytotoxic effects on cancer cells [98]. Lemongrass EO has been exhibited inhibition of human mouth epidermal carcinoma (KB) and murine leukemia cell lines (P388) [99]. Besides, citral, the major component of the EO of lemongrass, plays potential role as anti-proliferative against several types of cancer cells such as the two human prostate cancer cell line LNCaP and PC-3 [100], HL60, and ovarian cancer cells, U937 [101,102], cervical cancer cell lines [103], and breast cancer cell line, MCF-7 [104]. Interestingly, citral does not exert cytotoxicity to normal epithelial cells but exhibited toxic effects against human breast cancer cell lines, and confirmed its cancerspecific efficacy [105].

Although a large number of studies evinced the anticancer activity of lemongrass, scarce data are available on its mode of action. Studies based on different cancer cell types substantiated citral efficacy via activated procaspase-3, induction of apoptosis, and cell cycle arrest in the G2/M phase [106,107].

Table 1. Effects of different components of lemongrass on several distinct cancer cell lines

\begin{tabular}{|c|c|c|c|}
\hline Components & Experimental model & Mechanism of action & References \\
\hline Citral & $\begin{array}{l}\text { A549 (human lung carci- } \\
\text { noma) } \\
\text { NCI-H1975 (human lung } \\
\text { adenocarcinoma) } \\
\text { NCI-H1650 (human lung } \\
\text { adenocarcinoma) } \\
\text { NCI-H1299 (human lung } \\
\text { large cell carcinoma) }\end{array}$ & $\begin{array}{l}\text { Growth arrest of cell cy- } \\
\text { cle at sub G1 phase } \\
\text { Up-regulation of pro- } \\
\text { caspase- } 3 \\
\text { Decrease of Bcl-2 and in- } \\
\text { crease of expression of } \\
\text { Bax }\end{array}$ & [107] \\
\hline Citral & $\begin{array}{c}\text { Prostate cancer cells PC3 } \\
\text { and PC3M (metastatic) } \\
\text { Colony forming assay 10, } \\
15,25,50,100 \mu \mathrm{g} / \mathrm{ml}\end{array}$ & $\begin{array}{l}\text { Inhibition of colony } \\
\text { formation, suppression } \\
\text { of expression of AMPK } \\
\text { pathway genes SREBP1, } \\
A C C, H M G R \\
216 \text { up-regulated genes } \\
396 \text { downregulated genes } \\
\text { Apoptosis, block of } \\
\text { colony formation and } \\
\text { migration }\end{array}$ & [109] \\
\hline Citral & $\begin{array}{l}\text { Human colorectal cancer } \\
\text { HCT116 and HT29 cells }\end{array}$ & $\begin{array}{c}\text { Induction of } \\
\text { phosphorylation of p53, } \\
\text { triggering ROS } \\
\text { mediated mitochondrial } \\
\text { intrinsic apoptosis } \\
\text { cytotoxicity }\end{array}$ & [111] \\
\hline
\end{tabular}




\begin{tabular}{|c|c|c|c|}
\hline Geraniol & $\begin{array}{c}\text { A549 human lung } \\
\text { adenocarcinoma cells in } \\
\text { culture and in vivo in nude } \\
\text { mice }\end{array}$ & $\begin{array}{l}\text { Decrease of level of } \\
\text { membrane-bound Ras } \\
\text { protein, decreased the } \\
\text { level of cholesterol and } \\
\text { HMGCR protein }\end{array}$ & [112] \\
\hline Geraniol & $\begin{array}{c}\text { In vitro murine endothelial- } \\
\text { like eEND2 cells and } \\
\text { HDMEC (dermal } \\
\text { microvascular endothelial } \\
\text { cells), } \\
\text { In vivo, CT26 cell lines } \\
\text { from undifferentiated } \\
\text { colon carcinoma of the } \\
\text { BALB/ c mouse }\end{array}$ & $\begin{array}{l}\text { block of VEGF/ VEGFR } \\
\text { signal transduction and } \\
\text { suppression of cAKT } \\
\text { and ERK signalling } \\
\text { pathways }\end{array}$ & [113] \\
\hline Geraniol & $\begin{array}{c}\text { Human hepatoma } \\
\text { (HepG2) and human lung } \\
\text { adenocarcinoma (A549) } \\
\text { cell lines }\end{array}$ & $\begin{array}{l}\text { growth arrest in G0/G1 } \\
\text { interphase of the cell } \\
\text { cycle, increased the } \\
\text { production of ROS }\end{array}$ & [114] \\
\hline Citronellol & $\begin{array}{l}\text { In vitro, non-small lung } \\
\text { cancer cell (NCI-H1299) In } \\
\text { vivo, injected NCI-H1299 } \\
\text { into BALB/c nude mice }\end{array}$ & $\begin{array}{l}\text { Arrest of cell cycle at G1 } \\
\text { phase, down-regulation } \\
\text { of expression of cyclin } \\
\text { E, and cyclin D, } \\
\text { increase in expression } \\
\text { of TNF- } \alpha \text {, and } \\
\text { activation of RIP1/RIP }\end{array}$ & [115] \\
\hline Citronellol & $\begin{array}{l}\text { Triple negative breast } \\
\text { cancer MDA-MB- } 231 \text { cell } \\
\text { line }\end{array}$ & $\begin{array}{l}\text { Decrease in expression } \\
\text { of Bcl-2 gene and } \\
\text { protein and increase in } \\
\text { Bax expression. }\end{array}$ & [116] \\
\hline Citronellol & $\begin{array}{l}\operatorname{DMBA}(7,12- \\
\text { dimethylbenz }(a) \\
\text { anthracene }) \text { induced } \\
\text { mammary cancer in rats }\end{array}$ & $\begin{array}{l}\text { Down-regulation of } \\
\text { expression of NF-kB, } \\
\text { IL-6, and TNF- } \alpha \text {. } \\
\text { Suppression of activity } \\
\text { of COX-2. }\end{array}$ & [117] \\
\hline$\alpha$-bisabolol & $\begin{array}{l}\text { CML-T1, Jurkat, and HeLa } \\
\text { cell lines }\end{array}$ & $\begin{array}{l}\text { cytotoxicity via } \\
\text { mitochondria and } \\
\text { lysosome-initiated } \\
\text { caspase cascade and } \\
\text { induction of autophagy } \\
\text { and apoptosis }\end{array}$ & [118] \\
\hline$\alpha$-bisabolol & $\begin{array}{l}\text { KLM1, KP4, and Panc } 1 \\
\text { human pancreatic cancer } \\
\text { cell lines }\end{array}$ & $\begin{array}{l}\text { Up-regulation of } \\
\text { KISSIR }\end{array}$ & [119] \\
\hline$\alpha$-bisabolol & $\begin{array}{l}\text { Endometrial cancer cell } \\
\text { lines RL95-2, ECC001, } \\
\text { ECC003 } \\
\text { Ishikawa cell line }\end{array}$ & $\begin{array}{l}\text { Decrease of activity of } \\
\text { COX-2, induction in } \\
\text { PARP cleavage, } \\
\text { increase of apoptosis }\end{array}$ & {$[120]$} \\
\hline
\end{tabular}




\begin{tabular}{|c|c|c|c|}
\hline & ECC E6/E7 cell line & $\begin{array}{l}\text { via XIAP/ caspase } 3 \\
\text { pathway }\end{array}$ & \\
\hline Limonene & $\begin{array}{l}\text { Bladder cancer line T24; } \\
\text { colon cancer LS174T line } \\
\text { Bladder cancer cells; }\end{array}$ & $\begin{array}{l}\text { Arrest of cell cycle in } \\
\text { the G2/M phase; block } \\
\text { of cancer cell migration; } \\
\text { apoptosis; inhibition of } \\
\text { PI3K/AKT pathway }\end{array}$ & {$[121,122,141]$} \\
\hline & & $\begin{array}{l}\text { induces cell cycle G2/M, } \\
\text { suppresses migration. } \\
\text { Induces chromatin } \\
\text { concentration, nuclear } \\
\text { fragmentation, } \\
\text { increases Bax, caspase } \\
\text { 3, decreases Bcl-2 }\end{array}$ & \\
\hline Linalool & $\begin{array}{l}\text { HeLa, } \\
\text { H520 lung cancer line, } \\
\text { BCC-1/KMC skin cancer }\end{array}$ & Anti-proliferative & {$[170]$} \\
\hline
\end{tabular}

Citral consists of a double bond in conjugation with an aldehyde ( $\alpha, \beta$-unsaturated) group in its core structure, that serves as a potent caspase 3 activator, responsible for proapoptotic activity [106]. Moreover, citral-induced apoptotic activity was associated with DNA fragmentation and induced caspase 3 activity against hematopoietic cancer cell lines and ovarian cancer cell lines. The Src-tyrosine kinase is expressed in small cell lung cancer and can phosphorylate transcription factor Stat3(Y705) [123], which sequentially enhances the expression of downstream genes engaged in anti-apoptotic activity i.e Bcl-xL and Mcl1 [124]. An experimental study showed the inhibitory effects of lemongrass EO and citral on phosphorylation of $\operatorname{Src}(\mathrm{Y} 416)$ blocking its activation, resulting in reduced phosphorylation of Stat3 (Y705). Non-phosphorylated Stat3 disrupts cell growth and signal pathways that upregulate the expression of Bcl-xL and Mcl-1 [125]. Citral dependent apoptosis induction has also been observed against prostate cancer cell lines. Citral induced gene activation initiates AMPK (an enzyme necessary in the fatty acid metabolism) phosphorylation resulting in the activation of BAX and downregulation of Bcl-2, which initiates an apoptosis cascade in prostate cancer cell lines [108]. Citralmediated breast tumor growth inhibition via inhibition of ALDH1A3 was reported [126]. Up-regulation of retinoic acid (RA) signalling by ALDH1A3 can cause breast cancer growth, and citral inhibited the expression of RA inducible genes mediated by ALDH1A3 [126]. Microtubule affinity regulating kinase 4 (MARK4), an AMP-activated protein kinase [127], is reported to mediate apoptosis, inflammation, and distinct regulatory pathways [128]. Alterations in MARK4 expression hamper the cell cycle and eventually cause cancer. Citral potentially binds to MARK4 and inhibits its kinase activity, and is being considered an effective strategy to prevent the growth of cancer cells and other MARK4 associated diseases [129]. Citral has been reported inducing the phosphorylation of p53 protein and the expression of Bax while reducing the expression of anti-apoptotic factor Bc-2 and BclxL in human colorectal cancer lines i.e HT116 and HT29 [110]. Citral interferes with the ERK1/2 pathway and reduces the translocation of ERK1/2 protein to the nucleus. There is a certain possibility of the involvement of ERK1/2 in melanoma carcinogenesis and progression in presence of mutated $N$-Ras and $B$-Raf. Therefore, citral could negatively affect cancer growth by inhibiting the final step of the MAPK cascade [130]. 
Geraniol, the second major constituent of lemongrass EO, has garnered heed for its potentiality in cancer treatment. It has been reported that geraniol induces the production of reactive oxygen species (ROS) and inhibits the phosphorylation of tyrosine kinases, which, in turn, induce apoptosis of cancer cells [131]. Several studies have been conducted to gain insights into its anti-cancer activity [112-114]. Ornithine decarboxylase (ODC) plays a prime role in the synthesis of polyamines, providing stabilization to DNA structure [132]. A decrease in ODC activity after geraniol treatment has been observed in the intestinal adenocarcinoma Caco-2 cell line, which, in turn, caused DNA synthesis inhibition and cell cycle arrest in the $S$ phase [132]. Polyamine metabolism is a potential target in the development of cancer-preventive drugs, therefore, geraniol mediated decline in ODC activity might have a useful clinical role [133]. Geraniol-induced inhibition of the proliferation of A453 and A549 human lung cancer cell lines has been reported. Geraniol alters the tubulin polymerization and disrupts the active property of both the studied cell lines, resulting in cell apoptosis. Geraniol arrested the G0/G1 phase in A431 cells, with no effects on sub-diploid cells, and the G2/M phase of A549 with increased population of sub-diploid cells, in a dose-dependent manner. Inhibitory effects of geraniol might be interrelated with the observed alteration in the ODC activity [134]. Geraniol caused inhibition of cell cycle progression, exerting altered expression of cyclins D1, A, B1, CDK2, and cyclin kinase inhibitor proteins p21 and p27 [135]. Geraniol has been reported to induce the expression of pro-apoptotic proteins Bcl-2, Bax, Bak, and caspase3/8/9 in several human cancer cell lines [114,136]. Moreover, the considerable increase in these proteins indicates that geraniol induces apoptosis through the mitochondrial intrinsic pathway [137]. The antiangiogenic activity of geraniol has been confirmed by both in vivo and in vitro studies. Geraniol suppresses the endothelioma cell line and reduces the Ki67-positive cells and CD3-microvessel, by suppressing the expression of VEGFR-2 in Balb/c mice [138]. This activity might play a role in reducing tumor growth, as the tumor needs a new blood vessel to grow. Geraniol arrested the proliferation of two pancreatic cancer cell lines i.e MIA PaCa-2 and BxPC in hamsters when injected with PC-1 pancreatic ductal adenocarcinoma cells. In both the cell lines, it arrested the G1 phase of the cell cycle along with increased expression of cyclin kinase inhibitor proteins i.e p21 ${ }^{\mathrm{cip} 1}$ and $\mathrm{p}^{27 \mathrm{kip} 1}$ while suppressed those of cyclin A, B1, and CDK 2 [139].

D-limonene, another constituent of lemongrass EO, was also reported to possess antineoplastic activity. D-limonene enhances the activity of carcinogen metabolizing enzymes such as cytochrome P450, responsible for the conversion of carcinogens into less harmful forms and blocks their interaction with DNA [140]. Treatment of D-limonene on LS174T human colon cancer cells inhibited the P13K/Akt pathway, and induced cell apoptosis. An increase in PARP cleavage and activation of caspase- 3 indicates the involvement of mitochondrial apoptotic pathway [121]. Limonene-mediated induction of apoptosis via increased expression of Bax and caspase- 3 and decreased Bcl-2 expression has been reported in T24 bladder cancer cells. Moreover, Limonene arrested the cell cycle in the G2/M phase and wound healing and transwell assay using Matrigel has confirmed the limonene mediated suppression of cancer cell migration and invasion [141]. Another component of the EO of lemongrass, citronellol, is also found to exert cytotoxic effects on several cancer cell lines $[115,116,142]$. Citronellol showed its anti-cancer activity via increased reactive oxygen species production, alterations in mitochondrial permeability, DNA fragmentation, changes in cytochrome c activities, and activation of caspase, against the MCF-7 human mammary tumor cell line [142]. The cytotoxicity of $\alpha$-bisabolol has been reported against human and rat malignant glioma cancer cell lines. In $\alpha$-bisabolol treated cell line, rapid loss of inner transmembrane potential and an increase in cytochrome-c translocation indicate that $\alpha$-bisabolol can trigger apoptosis through mitochondrial 
intrinsic pathway [143]. Another experimental study has confirmed the cytotoxic effect of $\alpha$-bisabolol against several cancer cell lines. $\alpha$-bisabolol arrested cell cycle and initiated cancer cell death via BID (BH3-only activator protein)- dependent mechanism [144]. It induces the permeability of the outer mitochondrial membrane and plays crucial role during apoptosis [145]. $\alpha$-bisabolol induced damage to lysosomal and mitochondrial membranes via BID resulted in autophagy, and regulated cell death, enlightens its mode of action [144].

All of the mentioned components of lemongrass EO have presented their chemopreventative effects via arrest of different phases of the cell cycle, suppression of cyclins and cyclin-dependent kinases, DNA fragmentation, and anti-angiogenic activity, against different cancer cell lines. Several distinct signalling pathways have been reported in different experimental studies exhibiting anti-cancer activities of these mentioned components (Table 1).

It should be taken into consideration that often individual components were shown not effective as the essential oil, possibly because association of multiple components potentiates the activity of each molecule. LEO effects on doxorubicin-resistant ovarian carcinoma cells were shown not dependent on citral [146]. The natural mixture of bioactives present in LEO is responsible for the beneficial effects, such as regulation of multidrug resistance and P-glycoprotein efflux pump inhibition in human ovarian carcinoma cells [146] and colon cancer cells [147].

Furthermore, other studies showed anticancer effect of LEO, while anticancer activity could not be attributed to its single constituents [148]. Anticancer activity of essential plant oils has been usually used as a paragon to compare essential oils from different sources. For instance, zingiber essential oil (ZEO) components nerol, citral, limonene, pinene, and camphene sum up to $55-60 \%$ of ZEO bioactives. ZEO was shown to be active against colorectal cancer in rats [149]. On the other side, when specific bioactives have been studied as anti-cancer agents, pleiotropic effects have been observed, without precise indication of the main target or signalling pathway. For instance, resveratrol and stilbenes are known to regulate different signalling pathways [150]. Biochemical interaction with enzymes, regulation of non-coding RNAs, and activation of signalling pathways and transcription factors are among the main effects observed.

Epigenetic modifications play a key role in cancer proliferation. Many chromatin remodeling complex components are found mutated, silenced, or overexpressed in cancers. Epigenetic mechanisms may be taken into account to explain the regulation of various protein-coding and protein non-coding genes. One of the causes of gene transcription is the level of DNA methylation on promoters, controlled by DNA methyltransferases. A second mechanism is dependent on chromatin remodelling complexes and the recruitment of Polycomb repressing complexes and histone modifying enzymes [151]. A great involvement of non-coding RNAs is at the basis of these mechanisms: therefore, expression of long and small non-coding RNAs determines whether an antioncogenic pathway is repressed or downregulated, or oncogenes are set free to induce cell transformation. The most well-known group of RNAs are microRNAs $[152,153]$. When they are abundant, they silence mRNA transcription by sequestering them and destining them to degradation. Long non-coding RNAs such as competing endogenous RNAs (ceRNAs) may sponge a group of miRNAs and the relative abundance determines if the miRNA can exert its effects or is bound to the sponge [154]. Therefore chromatin accessibility (opening or compaction), access to transcription machinery, and promoter methylation are the principal mechanisms that are targeted by plant extracts, essential oils, and individual bioactives. This has been clearly reviewed for stilbenes [150] and other plant bioactives [154]. 


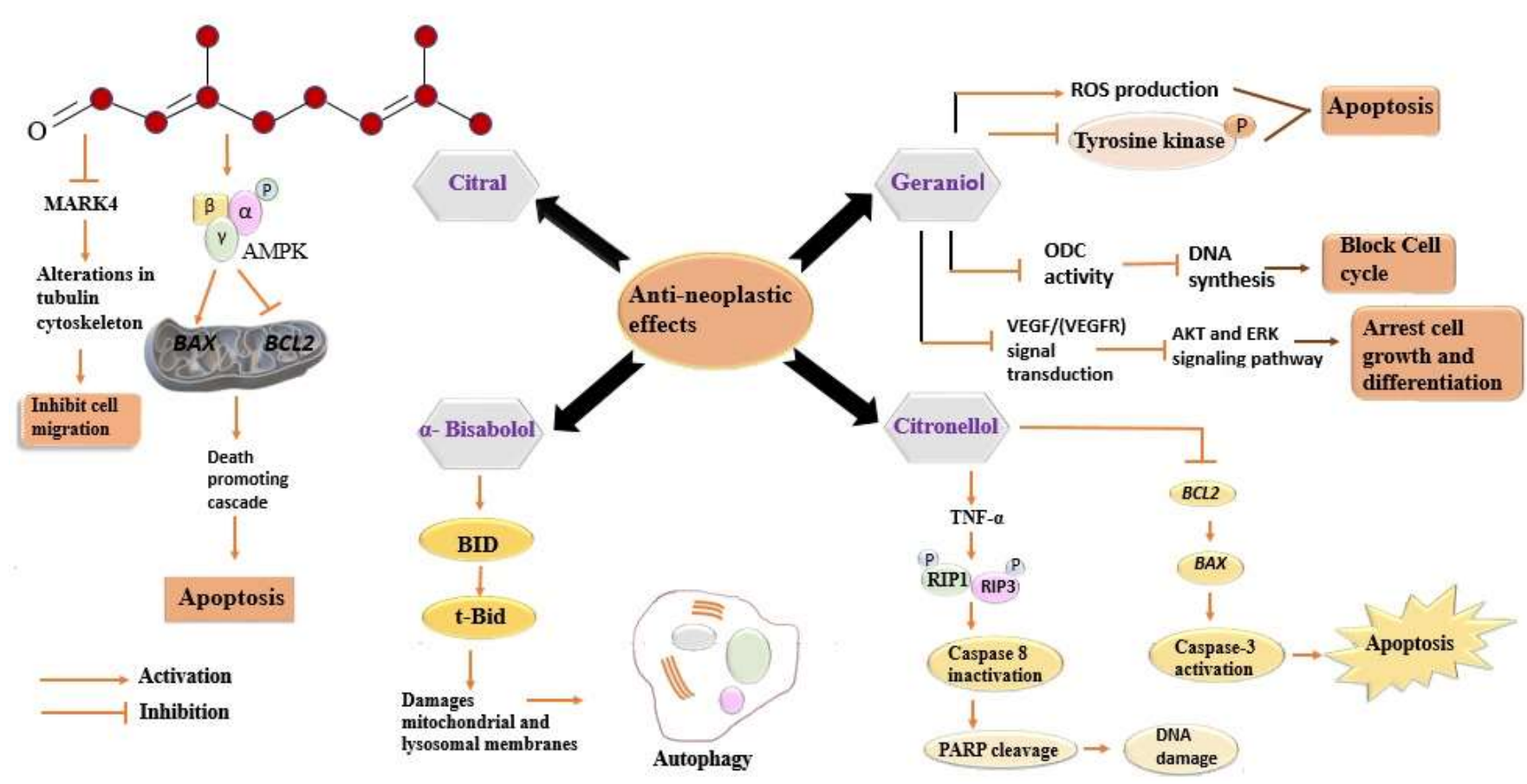

Figure 3. Distinctive signalling pathways activated in cancer cells via different components of LEO. Every component acts differently against cancer cells and involves diverse signalling pathways. All of the involved pathways lead to inhibition of cell migration, cell cycle, and DNA synthesis. All of these events eventually cause cell death (apoptosis). MARK4, Microtubule affinity-regulating kinase 4; AMPK, 5' adenosine monophosphate-activated protein kinase; BAX, BCl2-associated X protein; BCL2, B-cell lymphoma 2; BID, BH3-only activator protein; tBid, truncated Bid, ROS, reactive oxygen species; ODC, ornithine decarboxylase; VEGF, vascular endothelial growth factor; VEGFR, vascular endothelial growth factor receptor; AKT, Ak strain transforming; ERK, extracellular regulated kinase; TNF- $\alpha$, tumor necrosis factor; RIP1, receptor-interacting serine-threonine protein kinase 1; RIP3, receptor-interacting serine-threonine protein kinase 3; PARP, poly ADP ribose polymerase, DNA, deoxyribonucleic acid.

\subsection{Miscellaneous}

The lemongrass tea relieves stress, removes cough and nasal congestion. The LEO is exploited in the production of various mouthwashes [155]. The distinct fragrance of lemongrass is exploited in the flavour and perfume industries. Asian cuisine has long used lemongrass in numerous traditional dishes preparation. LEO coating on berries slows down the increase in total anthocyanin concentration, a known marker for the ripening of berry fruits, thus delaying berry ripening and spoilage [156]. The lemongrass oil and its components such as citral, myrcene, and citronellol show anti-malarial potential against Plasmodium spp. as well as confer total mortality of stage III and stage IV larvae in Anopheles funestus s.s [157-159]. Furthermore, multiple reports suggest LEO can suppress larval growth and production in various insects [160-164]. Lemongrass active constituent citral in combination with other components can regulate neuroreceptor activities, signal transduction, hormonal balance, membrane integrity, and cytotoxicity in insects $[165,166]$. Other minor components including caryophyllene, caryophyllene oxide, and germacrene$\mathrm{D}$ discourage insect invasion and are effective against common houseflies and mosquitoes as well [167]. LEO can retard the activities of different neurotransmitters such as acetylcholine esterase and octopamine, activate olfactory receptor neurons, and induce related neurotoxic responses in insects $[11,168,169]$. Concerning this, a recent review [11] can be referred to for further reading on the insecticidal property of LEO and its underlying mechanism. (Figure 4) 


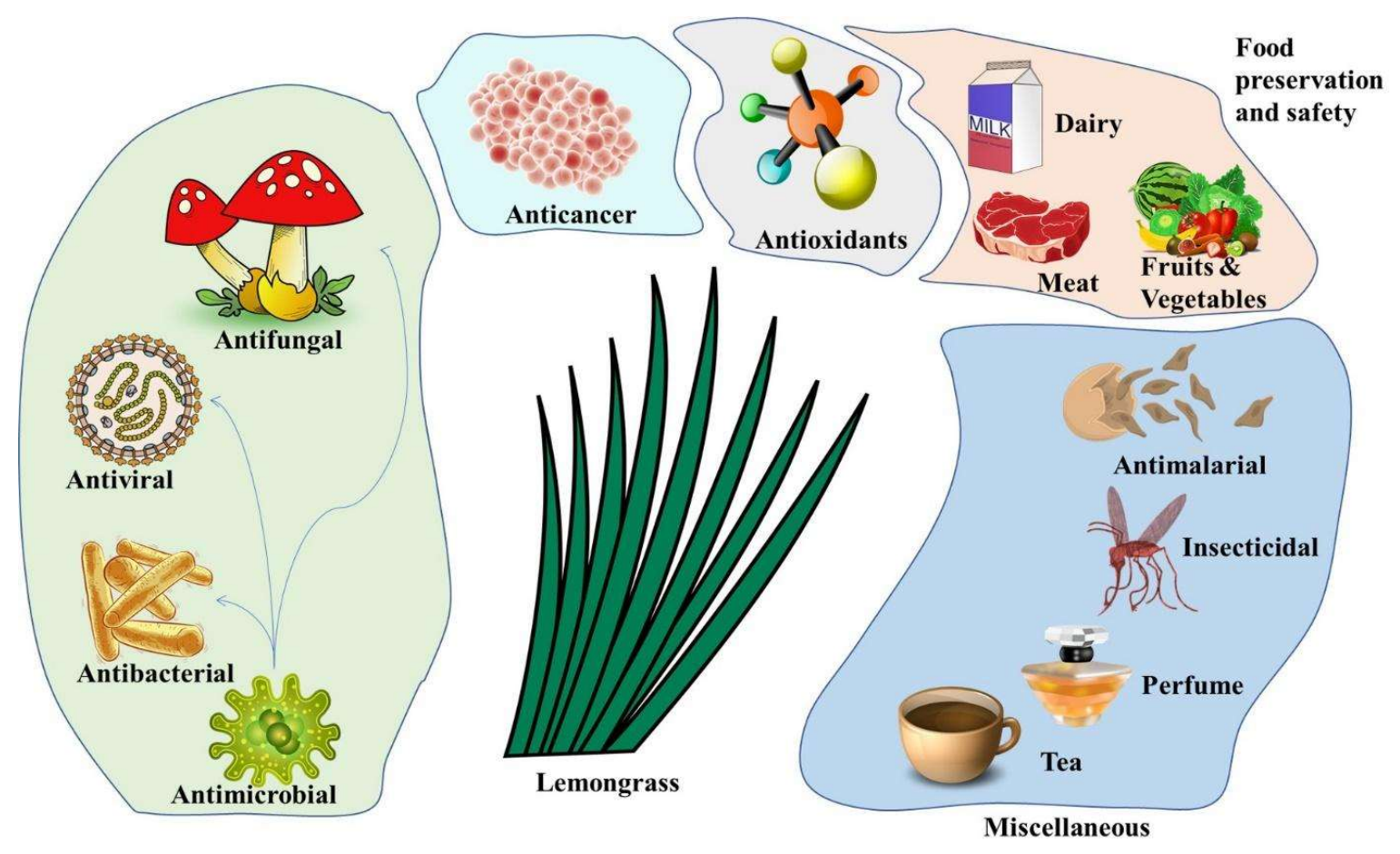

Figure 4. The relevance of lemongrass in the contemporary world. The past decades observed a sudden rise in the lemongrass economy given its unique properties and sustainable nature. The lemongrass and its essential oil consist of multiple bioactive components which enrich lemongrass with antibacterial, antifungal, and antiviral activities. This bioactivity is exploited in preserving meat, fruits, vegetables, and dairy products. The antioxidant and cytotoxic potential of lemongrass has rendered promising results in recent cancer studies putting lemongrass again in the spotlight. Additionally, the figure traces the contours of multiple other lemongrass-driven benefits such as tea and perfumes and combating malaria and insects.

\section{Conclusions and future trends}

The bioactive phytoconstituents present in lemongrass essential oils exhibit a myriad of medicinal properties including antimicrobial, anticancer, antioxidant, insecticidal, and antimalarial activities. Although recent years have seen an upsurge in lemongrass production, it is still far behind the global demand. Given its potential applicability in diverse sectors, lemongrass farming requires a revolutionised future. Harvesting of plant metabolites from controlled growth conditions (hairy root cultures, greenhouse) may establish a standard production of individual LEO bioactive components. Moreover, since citral is considered as the key marker for lemongrass quality and medicinal potential, improved lemongrass varieties with higher citral content are the need of the hour. Although LEO and its constituents have shown anticancer activity in vitro, and in some case in animal studies, only few researchers up to now tested the delivery of its bioactive components combined with nanoparticles or delivery systems $[111,126,171]$. This is required in order to bypass the metabolism of bioactives by microbiota and by cellular enzymes, to provide stability and bioavailability at the active concentrations tested in the studies. The anticancer effect of lemongrass ethanolic extracts on cancer cells having an increased level of ROS was shown to affect the increase in apoptosis levels [172]. Thus, it is possible that different bioactive contents may be put in relationship with different aactivity against cancer cells. Additionally, further studies on the antioxidant and anticancer mechanisms exerted by lemongrass components are required either in vitro as well as in vivo, to validate these preliminar data. 


\begin{abstract}
Author Contributions: Conceptualization, M.M. and S.C.; resources, M.M.A.K.; writing-original draft preparation, M.M., S.C., M.A.K., P.P. and J.A.; writing-review and editing, P.P., D.K., M.M.A.K. and M.S.; visualization, P.P. and M.M.A.K.; supervision, P.P. and M.M.A.K.; project administration, P.P. and M.M.A.K.; funding acquisition, P.P. All authors have read and agreed to the published version of the manuscript.
\end{abstract}

Funding: This research was funded by Ministry of Productive Activitirs of Italy, PON02_00186_3417512 S.I.Mi.S.A.

Acknowledgments: The authors acknowledge Dr David Buss, Centre for Applied Entomology and Parasitology, School of Life Sciences, Keele University, United Kingdom, for his kind evaluation and revision of the present manuscript.

Conflicts of Interest: The authors declare no conflict of interest. The funders had no role in the design of the study; in the collection, analyses, or interpretation of data; in the writing of the manuscript, or in the decision to publish the results.

\title{
References
}

1. Shah, G.; Shri, R.; Panchal, V.; Sharma, N.; Singh, B.; Mann, A, S. Scientific basis for the therapeutic use of Cymbopogon citratus, stapf (Lemon grass). J. Adv. Pharm. Tecnol. Res. 2011, 2,3.

2. Srivastava, V.; Dubey, S.; Mishra, A. A Review on Lemon Grass: Agricultural and Medicinal Aspect. Int. Res. J. Pharm. 2013, 4, 42-44, doi:10.7897/2230-8407.04807.

3. Mukarram, M.; Khan, M.M.A.; Corpas, F.J. Silicon nanoparticles elicit an increase in lemongrass (Cymbopogon flexuosus (Steud.) Wats) agronomic parameters with a higher essential oil yield. J. Hazard. Mater. 2021, 412, doi:10.1016/j.jhazmat.2021.125254.

4. Joy, P.P.; Skaria, B.P.; Mathew, S.; Mathew, G.; Joseph, A.; Sreevidya, P.P. Lemongrass. Aromatic and medicinal plants research station, Odakkali. 2006, ISBN 0484265822.

5. Gaba, J.; Bhardwaj, G.; Sharma, A. Lemongrass. In Antioxidants in Vegetables and Nuts - Properties and Health Benefits. Springer Singapore. 2020, 75-103.

6. Aftab, K.; Ali, M.; Aijaz, P.; Beena, N.; Gulzar, H, J.; Sofia, Q.; Tahir, A, S. Determination of diferent trace and essential element in lemon grass samples by x-ray fluorescence spectroscopy technique. Int. Food Res. J. 2011, 18.

7. Haque, A.N.M.A.; Remadevi, R.; Naebe, M. Lemongrass (Cymbopogon): a review on its structure, properties, applications and recent developments. Cellulose. 2018, 25, 5455-5477. doi:10.1007/s10570-018-1965-2.

8. Skaria, B.P.; Joy, P.P.; Mathew, S.; Mathew, G. Lemongrass. In Handbook of Herbs and Spices. Elsevier Ltd 2006, 3, 400-419, ISBN 9781845691714.

9. Singh, K.M.; Jha, A. Medicinal and Aromatic Plants Cultivation in Bihar. India: Economic Potential and Condition for Adoption. 2008.

10. Gupta, A.K.; Ganjewala, D. A study on biosynthesis of "citral" in lemongrass (Cymbopogon flexuosus) cv. Suvarna. Acta Physiol. 2015, 37, 1-8, doi:10.1007/s11738-015-1989-2.

11. Mukarram, M.; Khan, M.M.A.; Zehra, A.; Choudhary, S.; Naeem, M.; Aftab, T. Biosynthesis of Lemongrass Essential Oil and the Underlying Mechanism for Its Insecticidal Activity. Medicinal and Aromatic Plants. 2021, 429-443.

12. Ganjewala, D.; Luthra, R. Essential oil biosynthesis and regulation in the genus Cymbopogon. Nat. Prod. Commun. 2010, 5, 163-172.

13. Ranade, S.S. Lemon grass. Int. J. Pharm. Sci. Rev. Res. 2015, 35.

14. Hanaa, A.M.; Sallam, Y.I.; El-Leithy, A.S.; Aly, S. E. Lemongrass (Cymbopogon citratus) essential oil as affected by drying methods. Ann. Agric. Sci. 2012, 57, 113-116.

15. Muturi, E.J.; Selling, G.W.; Doll, K.M.; Hay, W.T.; Ramirez, J.L. Leptospermum scoparium essential oil is a promising source of mosquito larvicide and its toxicity is enhanced by a biobased emulsifier. PLoS One. 2020, 15, 1-14, doi:10.1371/journal.pone.0229076.

16. Abdulazeez, M.A.; Abdullahi, A.S.; James, B.D. Lemongrass (Cymbopogon spp.) oils. In Essential oils in food preservation, flavor and safety. 2016, 509-516.

17. Meena, S.; Kumar, S.R.; Rao, D.K.V.; Dwivedi, V.; Shilpashree, H.B.; Rastogi, S.; Shasany, A.K.; Nagegowda, D.A. De Novo sequencing and analysis of lemongrass transcriptome provide first insights into the essential oil 
biosynthesis of aromatic grasses. Front. Plant Sci. 2016, 7, 1-15, doi:10.3389/fpls.2016.01129.

18. Sharma, P.R.; Mondhe, D.M.; Muthiah, S.; Pal, H.C.; Shahi, A.K.; Saxena, A.K.; Qazi, G.N. Anticancer activity of an essential oil from Cymbopogon flexuosus. Chem. Biol. Interact. 2009, 179, 160-168, doi:10.1016/j.cbi.2008.12.004.

19. Shendurse, A.M.; Sangwan, R.B.; Amit Kumar, R. V.; Patel, A.C.; Gopikrishna, G.; Roy, S.K. Phytochemical screening and antibacterial activity of lemongrass (Cymbopogon citratus) leaves essential oil. J. Pharmacogn. Phytochem. 2021, 10, 445-449.

20. Rossi, G.G.; Guterres, K.B.; Bonez, P.C.; Gundel, S.S.; Aggertt, V.A.; Siqueira, F.S.; Iurique, A.F.; Wagnerd, R.; Klein, B.; Santos, R.C.V.; Campos, M.M.A. Antibiofilm activity of nanoemulsions of Cymbopogon flexuosus against rapidly growing mycobacteria. Microb. Pathog. 2017, 113, 335-341.

21. Braga da Silva, N.; de Lucena Rangel, M.; Dias de Castro, R.; Muniz de Lima, J.; Roberto Cançado Castellano, L.; Maria Gondim Valença, A.; Leite Cavalcanti, A.; Francisco Chagas Almeida, R.; Pessoa, J.; Wilney Nascimento Padilha, W. Anti-Biofilm and Hemolytic Effects of Cymbopogon citratus (Dc) Stapf Essential Oil. Pesqui. Bras. Odontopediatria Clin. Integr. 2020, 19, 5011, doi:10.4034/PBOCI.2019.191.103.

22. Gao, S.; Liu, G.; Li, J.; Chen, J.; Li, L.; Li, Z.; Zhang, X.; Zhang, S.; Thorne, R.F.; Zhang, S. Antimicrobial Activity of Lemongrass Essential Oil (Cymbopogon flexuosus) and Its Active Component Citral Against Dual-Species Biofilms of Staphylococcus. Front. Cell. Infect. Microbiol. 2020, 10.

23. Manvitha, K.; Bidya, B. Review on pharmacological activity of Cymbopogon citratus. Int. J. Herb. Med. 2014, 1, 57.

24. Olorunnisola, S.K.; Asiyanbi, H.T.; Hammed, A.M.; Simsek, S. Biological properties of lemongrass: An overview. Int. Food Res. J. 2014, 21, 455-462.

25. Ekpenyong, C.E.; Akpan, E.; Nyoh, A. Ethnopharmacology, phytochemistry, and biological activities of Cymbopogon citratus (DC.) Stapf extracts. Chin. J. Nat. Med. 2015, 13, 321-337, doi:10.1016/S1875-5364(15)30023-6.

26. Adukwu, E.C.; Bowles, M.; Edwards-Jones, V.; Bone, H. Antimicrobial activity, cytotoxicity and chemical analysis of lemongrass essential oil (Cymbopogon flexuosus) and pure citral. Appl. Microbiol. Biotechnol. 2016, 100, 9619-9627, doi:10.1007/s00253-016-7807-y.

27. Hadjilouka, A.; Mavrogiannis, G.; Mallouchos, A.; Paramithiotis, S.; Mataragas, M.; Drosinos, E.H. Effect of lemongrass essential oil on Listeria monocytogenes gene expression. LWT - Food Sci. Technol. 2017, 77, 510-516, doi:10.1016/j.lwt.2016.11.080.

28. Li, M.; Liu, B.; Bernigaud, C.; Fischer, K.; Guillot, J.; Fang, F. Lemongrass (Cymbopogon citratus ) oil : A promising miticidal and ovicidal agent against Sarcoptes scabiei. PLoS Negl. Trop. Dis. 2020, 14, 1-10, doi:10.1371/journal.pntd.0008225.

29. Hacke, A.C.M.; Miyoshi, E.; Marques, J.A.; Pereira, R.P. Anxiolytic properties of Cymbopogon citratus (DC.) stapf extract, essential oil and its constituents in zebrafish (Danio rerio). J. Ethnopharmacol. 2020, 260, 113036.

30. Lee, J.; Seo, S.; Huh, M.; Lee, S.; Park, I. Reactive oxygen species mediated-antifungal activity of cinnamon bark (Cinnamomum verum) and lemongrass (Cymbopogon citratus) essential oils and their constituents against two phytopathogenic fungi. Pestic. Biochem. Phys. 2020, 168, 104644.

31. Avoseh, O.; Oyedeji, O.; Rungqu, P.; Nkeh-Chungag, B.; Oyedeji, A. Cymbopogon species; ethnopharmacology, phytochemistry and the pharmacological importance. Molecules. 2015, 20, 7438-7453, doi:10.3390/molecules20057438.

32. Naik, M.I.; Fomda, B.A.; Jaykumar, E.; Bhat, J.A. Antibacterial activity of lemongrass (Cymbopogon citratus) oil against some selected pathogenic bacterias. Asian Pac. J. Trop. Med. 2010, 3, 535-538, doi:10.1016/S19957645(10)60129-0.

33. Farias, P.K.S.; Lopes Silva, J.C.R.; de Souza, C.N.; da Fonseca, F.S.A.; Brandi, I.V.; Martins, E.R.; Azevedo, A.M.; de Almeida, A.C. Antioxidant activity of essential oils from condiment plants and their effect on lactic cultures and pathogenic bacteria. Cienc. Rural 2019, 49, doi:10.1590/0103-8478cr20180140.

34. Wan, J.; Zhong, S.; Schwarz, P.; Chen, B.; Rao, J. Physical properties, antifungal and mycotoxin inhibitory activities of five essential oil nanoemulsions: Impact of oil compositions and processing parameters. Food. Chem. 2019, 291, 199-206.

35. Minami, M.; Kita, M.; Nakaya, T.; Yamamoto, T.; Kuriyama, H.; Imanishi, J. The inhibitory effect of essential oils on herpes simplex virus type-1 replication in vitro. Microbiol. Immunol. 2003, 47, 681-684.

36. Wani, A.R.; Yadav, K.; Khursheed, A.; Rather, M.A. An updated and comprehensive review of the antiviral 
potential of essential oils and their chemical constituents with special focus on their mechanism of action against various influenza and coronaviruses. Microb. Pathogen. 2020, 104620.

37. Zulfa, Z.; Chia, C.T.; Rukayadi, Y. In vitro antimicrobial activity of Cymbopogon citratus (lemongrass) extracts against selected foodborne pathogens. Int. Food Res. J. 2016, 23, 1262.

38. Kalemba, D.; Kunicka, A. Antibacterial and Antifungal Properties of Essential Oils. CurR. Med. Chem. 2003, 10, 813-829.

39. Alagawany, M.; El-Saadony, M.T.; Elnesr, S.S.; Farahat, M.; Attia, G.; Madkour, M.; Reda, F.M. Use of lemongrass essential oil as a feed additive in quail's nutrition: its effect on growth, carcass, blood biochemistry, antioxidant and immunological indices digestive enzymes and intestinal microbiota. Poult. Sci. 2021, 100, 101172.

40. Sharma, S.; Habib, S.; Sahu, D.; Gupta, J. Chemical properties and therapeutic potential of citral, a monoterpene isolated from lemongrass. Med. Chem. 2019, 17, 2-12.

41. Singh, B.R.; Singh, R.K. Antimicrobial activity of lemongrass (Cymbopogon citratus) oil against microbes of environmental, clinical and food origin. Int. Res. J. Pharm. Pharmacol. 2011, 1, 228-236.

42. Lu, M.; Han, Z.; Xu, Y.; Yao, L. In Vitro and In Vivo Anti-Tobacco Mosaic Virus Activities of Essential Oils and Individual Compounds. J. Microbiol. Biotechnol. 2013, 23, 771-778, doi:10.4014/jmb.1210.10078.

43. Negrelle, R.R.B.; Gomes, E.C. Cymbopogon citratus (DC.) Stapf : chemical composition and biological activities. Rev. Bras. Pl. Med. 2007, 9, 80-92.

44. Vazirian, M.; Kashani, S.T.; Ardekani, M.R.S.; Khanavi, M.; Jamalifar, H.; Fazeli, M.R.; Toosi, A.N. Antimicrobial activity of lemongrass (Cymbopogon citratus (DC) Stapf.) essential oil against food-borne pathogens added to cream-filled cakes and pastries. J. Essent. Oil Res. 2012, 24, 579-582, doi:10.1080/10412905.2012.729920.

45. Cai, Z.; Remadevi, R.; Al Faruque, M.; Setty, M.; Fan, L.; Haque, A.N.M.A.; Naebe, M. Fabrication of a costeffective lemongrass (Cymbopogon citratus) membrane with antibacterial activity for dye removal. RSC advances. 2019, 9, 34076-34085.

46. Raybaudi-Massilia, R.M.; Mosqueda-Melgar, J.; Martin-Belloso, O. Antimicrobial Activity of Essential Oils on Salmonella Enteritidis, Escherichia coli, and Listeria innocua in Fruit Juices View project Quality of fresh-cut tomatoes subjected to pulsed light (PL) treatments View project. Artic. J. Food Prot. 2006, doi:10.4315/0362-028X69.7.1579.

47. Balakrishnan, B.; Paramasivam, S.; Arulkumar, A. Evaluation of the lemongrass plant (Cymbopogon citratus) extracted in different solvents for antioxidant and antibacterial activity against human pathogens. Asian Pacific J. Trop. Dis. 2014, 4, doi:10.1016/S2222-1808(14)60428-X.

48. Mishra, D.; Khare, P.; Singh, D.K.; Luqman, S.; Kumar, P.V.A.; Yadav, A.; Das, T.; Saikia, B.K. Retention of antibacterial and antioxidant properties of lemongrass oil loaded on cellulose nanofibre-poly ethylene glycol composite. Ind. Crop. Prod. 2018, 114, 68-80.

49. Moore-Neibel, K.; Gerber, C.; Patel, J.; Friedman, M.; Ravishankar, S. Antimicrobial activity of lemongrass oil against Salmonella enterica on organic leafy greens. Wiley Online Libr. 2012, 112, 485-492, doi:10.1111/j.13652672.2011.05222.x.

50. Kotzekidou, P.; Giannakidis, P.; Boulamatsis, A. Antimicrobial activity of some plant extracts and essential oils against foodborne pathogens in vitro and on the fate of inoculated pathogens in chocolate. LWT Food Sci. Technol. 2008, 41, 119-127.

51. Boukhatem, M.N.; Kameli, A.; Ferhat, M.A.; Saidi, F.; Tayebi, K. The food preservative potential of essential oils: Is lemongrass the answer? J. fur Verbraucherschutz Leb. 2014, 9, 13-21, doi:10.1007/s00003-013-0852-x.

52. Aiemsaard, J.; Aiumlamai, S.; Aromdee, C.; Taweechaisupapong, S.; Khunkitti, W. The effect of lemongrass oil and its major components on clinical isolate mastitis pathogens and their mechanisms of action on Staphylococcus aureus DMST 4745. Res. Vet. Sci. 2011, 91, 31-37, doi:10.1016/j.rvsc.2011.01.012.

53. Takaisi-Kikuni, N.; Krüger, D.; Gnann, W.; Wecke, J. Microcalorimetric and electron microscopic investigation on the effects of essential oil from Cymbopogon densiflorus on Staphylococcus aureus. Microbios. 1996, 88, 55-62.

54. Peichel, C.; Nair, D.V.T.; Dewi, G.; Donoghue, A.M.; Reed, K.M.; Johny, A.K. Effect of lemongrass (Cymbopogon citratus) essential oil on the survival of multidrug-resistant Salmonella enterica serovar Heidelberg in contaminated poultry drinking water. J. Appl. Poult. Res. 2019, 28, 1121-1130.

55. Dewi, G.; Nair, D.V.T.; Peichel, C.; Johnson, T.J.; Noll, S.; Johny, A.K. Effect of lemongrass essential oil against multidrug-resistant Salmonella Heidelberg and its attachment to chicken skin and meat. Poult. Sci. 2021, 101116. 
56. Gill, A.O.; Holley, R.A. Mechanisms of bactericidal action of cinnamaldehyde against Listeria monocytogenes and of eugenol against L. monocytogenes and Lactobacillus sakei. Appl. Environ. Microbiol. 2004, 70, 5750-5755, doi:10.1128/AEM.70.10.5750-5755.2004.

57. Hassoun, A.; Emir Çoban, Ö. Essential oils for antimicrobial and antioxidant applications in fish and other seafood products. Trends Food Sci. Technol. 2017, 68, 26-36, doi:10.1016/j.tifs.2017.07.016.

58. Swamy, M.; Akhtar, M.S.; Sinniah, U.R. Antimicrobial properties of plant essential oils against human pathogens and their mode of action: an updated review. Evid. Based Complement. Alternat. Med. 2016.

59. Devi, M.A.; Sahoo, D.; Singh, T.B.; Rajashekar, Y. Toxicity, repellency and chemical composition of essential oils from Cymbopogon species against red flour beetle Tribolium castaneum Herbst (Coleoptera: Tenebrionidae). J. fur Verbraucherschutz Leb. 2020, 15, 181-191, doi:10.1007/s00003-019-01264-y.

60. Ju, J.; Xie, Y.; Guo, Y.; Cheng, Y.; Qian, H.; Yao, W. Application of edible coating with essential oil in food preservation. Crit. Rev. Food Sci. Nutr. 2019, 59, 2467-2480, doi:10.1080/10408398.2018.1456402.

61. Irkin, R.; Korukluoglu, M. Effectiveness of cymbopogon citratus 1. essential oil to inhibit the growth of some filamentous fungi and yeasts. J. Med. Food. 2009, 12, 193-197, doi:10.1089/jmf.2008.0108.

62. Tzortzakis, N.G.; Economakis, C.D. Antifungal activity of lemongrass (Cympopogon citratus L.) essential oil against key postharvest pathogens. Innov. Food Sci. Emerg. Technol. 2007, 8, 253-258, doi:10.1016/j.ifset.2007.01.002.

63. Dong, L.M.; Thuy, D.T.K. Evaluation of the synergistic effect of ethanol and lemongrass oil against Aspergillus niger. J. Microbiol. Biotech. Food Sci. 2021, 1312-1316.

64. Abd-El Fattah, S.M.; Yahia Hassan, A.; Bayoum, H.M.; Eissa, H.A. The use of lemongrass extracts as antimicrobial and food additive potential in yoghurt. J. Am. Sci 2010, 6, 582-594.

65. Júnior, R.C.; Capucho, E.; Garcia, T.M.; Del Valle, T.A.; Campana, M.; Zilio, E.M.C.; Azevedo, E.B.; Morais, J.P.G. Lemongrass essential oil in sugarcane silage: Fermentative profile, losses, chemical composition, and aerobic stability. Anim. Feed Sci.Tech. 2020, 260, 114371.

66. Helal, G.A.; Sarhan, M.M.; Shahla, A.N.K.A.; Abou El-Khair, E.K. Effects of Cymbopogon citratus L. essential oil on the growth, morphogenesis and aflatoxin production of Aspergillus flavus ML2-strain. J. Basic Microbiol. 2007, 47, 5-15, doi:10.1002/jobm.200610137.

67. Alviano, W.S.; Mendonça-Filho, R.R.; Alviano, D.S.; Bizzo, H.R.; Souto-Padrón, T.; Rodrigues, M.L.; Bolognese, A.M.; Alviano, C.S.; Souza, M.M.G. Antimicrobial activity of Croton cajucara Benth linalool-rich essential oil on artificial biofilms and planktonic microorganisms. Oral Microbiol. Immunol. 2005, 20, 101-105, doi:10.1111/j.1399302X.2004.00201.x.

68. da Silva, C. de B.; Guterres, S.S.; Weisheimer, V.; Schapoval, E.E.S. Antifungal activity of the lemongrass oil and citral against Candida spp. Brazilian J. Infect. Dis. 2008, 12, 63-66, doi:10.1590/s1413-86702008000100014.

69. Tchinda, E.S.; Jazet, P.M.D.; Tatsadjieu, L.N.; Ndongson, B.D.; Amvam, P.H.Z.; Menut, C. Antifungal Activity of the Essential Oil of Cymbopogon citratus (Poaceae) Against Phaeoramularia angolensis. J. Essent. Oil Bear. Plants 2009, 12, 218-224, doi:10.1080/0972060X.2009.10643714.

70. Mishra, A.K.; Dubey, N.K. Evaluation of some essential oils for their toxicity against fungi causing deterioration of stored food commodities. Appl. Environ. Microbiol. 1994, 60, 1101-1105, doi:10.1128/aem.60.4.1101-1105.1994.

71. Masniyom, P.; Benjama, O.; Maneesri, J. Effect of turmeric and lemongrass essential oils and their mixture on quality changes of refrigerated green mussel (Perna viridis). Wiley Online Libr. 2012, 47, 1079-1085, doi:10.1111/j.1365-2621.2012.02944.x.

72. Jayasena, D.D.; Jo, C. Essential oils as potential antimicrobial agents in meat and meat products: A review. Trends Food Sci. Technol. 2013, 34, 96-108, doi:10.1016/j.tifs.2013.09.002.

73. Oh, Y.A.; Oh, Y.J.; Song, A.Y.; Won, J.S.; Song, K. Bin; Min, S.C. Comparison of effectiveness of edible coatings using emulsions containing lemongrass oil of different size droplets on grape berry safety and preservation. Lwt 2017, 75, 742-750, doi:10.1016/j.lwt.2016.10.033.

74. Artiga-Artigas, M.; Acevedo-Fani, A.; Martin-Belloso, O. Improving the shelf life of low-fat cut cheese using nanoemulsion-based edible coatings containing oregano essential oil and mandarin fiber. Food control 2017, 76 , $1-12$.

75. Frazão, G.G.S.; Blank, A.F.; de Aquino Santana, L.C.L. Optimisation of edible chitosan coatings formulations incorporating Myrcia ovata Cambessedes essential oil with antimicrobial potential against foodborne bacteria and natural microflora of mangaba fruits. LWT Food Sci.Technol. 2017, 79, 1-10. 
76. Yousuf, B.;Srivastava, A.K. Flaxseed gum in combination with lemongrass essential oil as an effective edible coating for ready-to-eat pomegranate arils. Int. J. Biol. Macromol. 2017, 104, 1030-1038.

77. Silveira, S.M.D.; Júnior, A.C.; Scheuerman, G.N.; Secchi, F.L., Vieira, C.R.W. Chemical composition and antimicrobial activity of essential oils from selected herbs cultivated in the South of Brazil against food spoilage and foodborne pathogens. Cienc. Rural. 2012, 42, 1300-1306.

78. Belewu, M.; Ahmed El-Imam, A.M.; Adeyemi, K.; Belewu, M.A.; Ahmed El-Imam, A.M.; Adeyemi, K.D.; Oladunjoye, S.A. Eucalyptus Oil and Lemon Grass Oil: Effect on Chemical Composition and Shelf-Life of Soft Cheese Milk and animal feed View project Aspergillus-fermented Jatropha curcas seed cake: Proximate composition and effects on biochemical indices in Wistar rats View project Eucalyptus Oil and Lemon Grass Oil: Effect on Chemical Composition and Shelf-Life of Soft Cheese. Environ. Nat. Resour. Res. 2012, 2, doi:10.5539/enrr.v2n1p114.

79. Kim, Y.; Khan, A.L.; Waqas, M.; Lee, I.; Lee, I. Silicon Regulates Antioxidant Activities of Crop Plants under Abiotic-Induced Oxidative Stress : A Review. Front. Plant Sci. 2017, 8, 1-7, doi:10.3389/fpls.2017.00510.

80. Feriotto, G.; Marchetti, N.; Costa, V.; Beninati, S.; Tagliati, F.; Mischiati, C. Chemical Composition of Essential Oils from Thymus vulgaris, Cymbopogon citratus, and Rosmarinus officinalis, and Their Effects on the HIV-1 Tat Protein Function. Chem. Bio. 2018, 15, doi:10.1002/cbdv.201700436.

81. Chiamenti, L.; Silva, F.P.D.; Schallemberger, K.; Demoliner, M.; Rigotto, C.; Fleck, J.D. Cytotoxicity and antiviral activity evaluation of Cymbopogon spp hydroethanolic extracts. Braz. J. Pharm. Sci. 2019, 55.

82. Asif, M.; Saleem, M.; Saadullah, M.; Yaseen, H.S.; Al Zarzour, R. COVID-19 and therapy with essential oils having antiviral, anti-inflammatory and immunomodulatory properties. Inflammopharmacology. 2020, 28, 11531161.

83. Mukarram, M.; Choudhary, S.; Kurjak, D.; Petek, A.; Khan, M.M.A. Drought: Sensing, signalling, effects and tolerance in higher plants. Physiol. Plant. 2021, 172, 1291-1300, doi:10.1111/ppl.13423.

84. Anggraeni, N.I.; Hidayat, I.W.; Saadah, D.; Rachman, E. Bioactivity of essential oil from lemongrass (Cymbopogon citratus Stapf) as antioxidant agent.AIP Conf. Proc. 2018, 1927, 1, 30007, doi:10.1063/1.5021200.

85. Karpagam, G.N.; Gayathri, R.; Vishnupriya, V. Bioactivity analysis of lemongrass oil. Asian J. Res Chem. 2016, 9, 903.

86. Selim, S.A. Chemical composition, antioxidant and antimicrobial activity of the essential oil and methanol extract of the Egyptian lemongrass Cymbopogon proximus Stapf. 2011, 62, 17-3495, doi:10.3989/gya.033810.

87. Mirghani, M.E.S.; Liyana, Y.; Parveen, J. Bioactivity analysis of lemongrass (Cymbopogan citratus) essential oil. Int. Food Res. J. 2012, 19, 569.

88. Tiwari, M.; Dwivedi, U.N.; Kakkar, P. Suppression of oxidative stress and pro-inflammatory mediators by Cymbopogon citratus D. Stapf extract in lipopolysaccharide stimulated murine alveolar macrophages. Food Chem. Toxicol. 2010, 48, 2913-2919.

89. Farooqi, A.A.; Fayyaz, S.; Poltronieri, P.; Calin, G.; Mallardo, M, Epigenetic deregulation in cancer: Enzyme players and non-coding RNAs. Semin. Cancer Biol. 2020.

90. Kapur, A.; Felder, M.; Fass, L.; Kaur, J.; Czarnecki, A.; Rathi, K.; Zeng, S.; Osowski, K.; Howell, C.; Xiong, M.; et al. Modulation of oxidative stress and subsequent induction of apoptosis and endoplasmic reticulum stress allows citral to decrease cancer cell proliferation. Sci. Rep. 2016, 6, 1-14.

91. Ndhlala, A.R.; Moyo, M.; Staden, J. Van molecules Natural Antioxidants: Fascinating or Mythical Biomolecules? Molecules 2010, 15, 6905-6930, doi:10.3390/molecules15106905.

92. Hartatie, E.S.; Prihartini, I.; Widodo, W.; Wahyudi, A. Bioactive Compounds of Lemongrass (Cymbopogon citratus) essential oil from different parts of the plant and distillation methods as natural antioxidant in broiler meat. a IOP Conf. Ser. Mater. Sci. Eng. 2019, 532, 012018, doi:10.1088/1757-899X/532/1/012018.

93. Hedges, L.J.; Lister, C.E. Nutritional attributes of herbs. Crop Food Res. 2007, 89.

94. Soares, M.O.; Vinha, A.F.; Barreira, S.V.P.; Coutinho, F.; Aires-Gonçalves, S.; Oliveira, M.B.P.P.; Pires, P.C.; Castro, A. Evaluation of Antioxidant and Antimicrobial Properties of the Angolan Cymbopogon Citratus Essential Oil With a View to Its Utilization as Food Biopreservative. J. Agric. Sci. 2013, 5, 36-45, doi:10.5539/jas.v5n7p36.

95. Nguefack, J.; Nguikwie, S.K.; Fotio, D.; Dongmo, B.; Zollo, P.H.A.; Leth, V.; Nkengfack, A.E.; Poll, L. Fungicidal potential of essential oils and fractions from Cymbopogon citratus, Ocimum gratissimum and Thymus vulgaris to control Alternaria padwickii and Bipolaris oryzae, two seed-borne fungi of rice (Oryza sativa L.). J. Essent. Oil Res. 
2007, 19, 581-587, doi:10.1080/10412905.2007.9699336.

96. Nguyen, C.V. Anticancer Activity of Natural Health Products (Dandelion Root, Lemongrass, and Hibiscus Extracts); A Study of Efficacy, Interaction, and Mechanism of Action 2019.

97. Parveen, A.; Akash, M.S.H.; Rehman, K.; Kyun, W.W. Anticancer activities of medicinal plants: modulation of p53 expression and induction of apoptosis. Critical Reviews ${ }^{\mathrm{TM}}$ in Eukaryotic Gene Expression 2016, 26.

98. Sharma, P.; Mondhe, D.; Muthiah, S.; Pal, H.; Shahi, A.; Saxena, A.; Qazi, G. Anticancer activity of an essential oil from Cymbopogon flexuosus. Chem. Interact. 2009, 179, 160-168.

99. Manosroi, J.; Dhumtanom, P.; Manosroi, A. Anti-proliferative activity of essential oil extracted from Thai medicinal plants on KB and P388 cell lines. Cancer Lett. 2006, 235, 114-120.

100. Bailly, C. Targets and pathways involved in the antitumor activity of citral and its stereo-isomers. Eur. J. Pharmacol. 2020, 871, 172945.

101. Liu, Y.; Whelan, R.J.; Pattnaik, B.R.; Ludwig, K.; Subudhi, E.; Rowland, H.; Claussen, N.; Zucker, N.; Uppal, S.; Kushner, D.M.; et al. Terpenoids from Zingiber officinale (Ginger) Induce Apoptosis in Endometrial Cancer Cells through the Activation of p53. PLoS One 2012, 7, doi:10.1371/journal.pone.0053178.

102. Idrees, M.; Hakkim, F.L.; Naikoo, G.A.; Hassan, I.U. Recent advances in extraction, characterization, and potential use of citral. Natural Bio-active Compounds 2019, 3, 225-236, ISBN 9789811374388.

103. Halabi, M.; Sheikh, B. Anti-proliferative effect and phytochemical analysis of Cymbopogon citratus extract. Biomed Res. Int. 2014.

104. Najar, B.; Shortrede, J.E.; Pistelli, L.; Buhagiar, J. Chemical Composition and in Vitro Cytotoxic Screening of Sixteen Commercial Essential Oils on Five Cancer Cell Lines. Chem. Biodivers. 2020, 17, doi:10.1002/cbdv.201900478.

105. Patel, P.; Thakkar, V.; Patel, J. Cellular effect of curcumin and citral combination on breast cancer cells: induction of apoptosis and cell cycle arrest. J. Breast Cancer 2015, 18, 225.

106. Dudai, N.; Weinstein, Y.; Krup, M.; Rabinski, T.; Ofir, R. Citral is a new inducer of caspase-3 in tumor cell lines. Planta Med. 2005, 71, 484-488, doi:10.1055/s-2005-864146.

107. Trang, D.T.; Hoang, T.K.V.; Nguyen, T.T.M.; Van Cuong, P.; Dang, N.H.; Dang, H.D.; Quang, T.N.; Dat, N.T. Essential Oils of Lemongrass (Cymbopogon citratus Stapf) Induces Apoptosis and Cell Cycle Arrest in A549 Lung Cancer Cells. Biomed Res. Int. 2020, 2020, doi:10.1155/2020/5924856.

108. Balusamy, S.R.; Perumalsamy, H.; Veerappan, K.; Huq, M,; Rajeshkumar, S.; lakshmi, T.; Kim, Y.J. Citral induced apoptosis through modulation of key genes involved in fatty acid biosynthesis in human prostate cancer cells: In silico and in vitro study. BioMed Res. Int. 2020.

109. Balusamy, S.R.; Ramani, S.; Natarajan, S.; Kim, Y.J.; Perumalsamy, H. Integrated transcriptome and in vitro analysis revealed anti-proliferative effect of citral in human stomach cancer through apoptosis. Sci. Rep. 2019, 9, $1-13$.

110. Sheikh, B.Y.; Sarker, M.M.R.; Kamarudin, M.N.A.; Mohan, G. Antiproliferative and apoptosis inducing effects of citral via p53 and ROS-induced mitochondrial-mediated apoptosis in human colorectal HCT116 and HT29 cell lines. Biomed. Pharma. 2017, 96, 834-846.

111. Izham, M.; Hussin, Y.; Aziz, M.; Yeap, S.; Rahman, H.S.; Masarudin, M.J.; Mohamad, N.E.; Abdullah, R.; Alitheen, N.B. Preparation and Characterization of Self Nano-Emulsifying Drug Delivery System Loaded with Citraland Its Antiproliferative Effect on Colorectal Cells In Vitro. Nanomaterials. 2019, 9, doi:10.3390/nano9071028.

112. Galle, M.; Crespo, R.; Kladniew, B.R.; Villegas, S.M.; Polo, M.; De Bravo, M.G. Suppression by Geraniol of the Growth of A549 Human Lung Adenocarcinoma Cells and Inhibition of the Mevalonate Pathway in Culture and In Vivo: Potential Use in Cancer Chemotherapy. Nutr. Cancer 2014, 66, 888-895, doi:10.1080/01635581.2014.916320.

113. Wittig, C.; Scheuer, C.; Parakenings, J.; Menger, M.D.; Laschke, M.W. Geraniol suppresses angiogenesis by downregulating vascular endothelial growth factor (VEGF)/VEGFR-2 signaling. PLoS One. 2015, 10, doi:10.1371/journal.pone.0131946.

114. Crespo, R.; Rodenak-Kladniew, B.E.; Castro, M.A.; Soberon, M.V.; Lavarias, S.M. Induction of oxidative stress as a possible mechanism by which geraniol affects the proliferation of human A549 and HepG2 tumor cells. Chem. Biol. Interact. 2020, 320, 109029.

115. Yu, W.; Lai, Y.J.; Ma, J.; Ho, C.T.; Hung, S.W.; Chen, Y.H.; Chen, C.T.; Kao, J.Y.; Wat, T.D. Citronellol induces 
necroptosis of human lung cancer cells via TNF- $\alpha$ pathway and reactive oxygen species accumulation. in vivo 2019, 33, 1193-1201, doi:10.21873/invivo.11590.

116. Ho, Y.; Suphrom, N.; Daowtak, K.; Potup, P.; Thongsri, Y.; Usuwanthim, K. Anticancer Effect of Citrus hystrix DC. Leaf Extract and Its Bioactive Constituents Citronellol and, Citronellal on the Triple Negative Breast Cancer MDA-MB-231 Cell Line. Pharmaceuticals. 2020, doi:10.3390/ph13120476.

117. Jayaganesh, R.; Pugalendhi, P.; Murali, R. Effect of citronellol on NF-kB inflammatory signaling molecules in chemical carcinogen-induced mammary cancer in the rat model. J. Biochem. Mol. Toxicol. 2020, 34, doi:10.1002/jbt.22441.

118. Rigo, A.; Vinante, F. The antineoplastic agent $\alpha$-bisabolol promotes cell death by inducing pores in mitochondria and lysosomes. Apoptosis. 2016, 21, 917-927, doi:10.1007/s10495-016-1257-y.

119. Uno, M.; Kokuryo, T.; Yokoyama, Y.; Senga, T.; Nagino, M. $\alpha$-Bisabolol inhibits invasiveness and motility in pancreatic cancer through KISS1R activation. Anticancer Res. 2016, 36, 583-589.

120. Fang, D.; Wang, H.; Li, M.; Wei, W. $\alpha$-bisabolol enhances radiotherapy-induced apoptosis in endometrial cancer cells by reducing the effect of XIAP on inhibiting caspase-3. Bio. Rep. 2019, 39.

121. Jia, S.S.; Xi, G.P.; Zhang, M.; Chen, Y.B.; Lei, B.; Dong, X.S.; Yang, Y.M. Induction of apoptosis by D-limonene is mediated by inactivation of Akt in LS174T human colon cancer cells. Oncol. Rep. 2013, 29, 349-354, doi:10.3892/or.2012.2093.

122. Xia, Y.; Chen, R.; Lu, G.; Li, C.; Lian, S.; Kang, T.W.; Do Jung, Y. Natural phytochemicals in bladder cancer prevention and therapy. Front. Onc. 2021, 11.

123. Harada, D.; Takigawa, N.; Kiura, K. The Role of STAT3 in Non-Small Cell Lung Cancer. Cancers (Basel). 2014, 6, 708-722, doi:10.3390/cancers6020708.

124. Frank, D.A. STAT3 as a central mediator of neoplastic cellular transformation. Cancer lett. 2007, 251, 199-210.

125. Maruoka, T.; Kitanaka, A.; Kubota, Y.; Yamaoka, G.; Kameda, T.; Imataki, O.; Dobashi, H.; Bandoh, S.; Kadowaki, N.; Tanaka, T. Lemongrass essential oil and citral inhibit Src/Stat3 activity and suppress the proliferation/survival of small-cell lung cancer cells, alone or in combination with chemotherapeutic agents. Int. J. Oncol. 2018, 52, 1738-1748, doi:10.3892/ijo.2018.4314.

126. Thomas, M.L.; De Antueno, R.; Coyle, K.M.; Sultan, M.; Cruickshank. B.M.; Giacomantonia, M.A.; Giacomantonia, C.A.; Duncan, R.; Marcato, P. Citral reduces breast tumor growth by inhibiting the cancer stem cell marker ALDH1A3. Mol. Onc. 2016, 10, 1485-1496.

127. Liu, Z.; Gan, L.; Chen, Y.; Luo, D.; Zhang, Z.; Cao, W.; Zhou, Z.; Lin, X.; Sun, C. Mark4 promotes oxidative stress and inflammation via binding to PPAR $\gamma$ and activating NF-kB pathway in mice adipocytes. Sci. Rep. 2016, 6, 112

128. Feng, M.; Tian, L.; Gan, L.; Liu, Z.; Sun, C. Mark4 promotes adipogenesis and triggers apoptosis in 3T3-L1 adipocytes by activating JNK1 and inhibiting p38MAPK pathways. Biol. Cell 2014, 106, 294-307, doi:10.1111/boc.201400004.

129. Naz, F.; Khan, F.I.; Mohammad, T.; Khan, P.; Manzoor, S.; Hasan, G.M.; Lobb, K.A.; Luqman, S.; Islam, A.; Ahmad, F.; Hassan, M.I. Investigation of molecular mechanism of recognition between citral and MARK4: A newer therapeutic approach to attenuate cancer cell progression. Int. J. Biol. Macromol. 2018, 107, 2580-2589.

130. Sanches, L.J.; Marinello, P.C.; Panis, C.; Fagundes, T.R.; Morgada-Diaz, J.A.; de-Freitas-Junior, J.C.M.; Cecchini, R.; Cecchini, A.L.; Luiz, R.C. Cytotoxicity of citral against melanoma cells: The involvement of oxidative stress generation and cell growth protein reduction. Tumor Biol. 2017, 39, doi:10.1177/1010428317695914.

131. Kim, S.H.; Park, E.J.; Lee, C.R.; Chun, J.N.; Cho, N.H.; Lee, S.; Kim, T.W.; Park, H.H.; So, I.; Jeon, J.H. Geraniol induces cooperative interaction of apoptosis and autophagy to elicit cell death in PC-3 prostate cancer cells. Int. J. Onc. 2012, 40, 1683-1690, doi:10.3892/ijo.2011.1318.

132. Maczka, W.; Wínska, K.; Grabarczyk, M. One Hundred Faces of Geraniol. Molecules. 2020, 25, 3303, doi:10.3390/molecules25143303.

133. Murray-Stewart, T.R.; Woster, P.M.; Casero Jr, R.A. Targeting polyamine metabolism for cancer therapy and prevention. Biochem. J. 2016, 473, 2937-2953.

134. Fatima, K.; Zahoor, I; Wani, A.; Meena, I Abha; Luqman, S. Geraniol exerts its antiproliferative action by modulating molecular targets in lung and skin carcinoma cells. Phytother. Res. 2021, doi:10.1002/ptr.7094.

135. Madan, K.; Devaki, T. Geraniol, a component of plant essential oils-a review of its pharmacological activities. 
Int. J. Pharm. Pharm. Sci. 2015, 7, 67-70.

136. Shen, X.; Cui, X.; Cui, H.; Jin, Y.; Jin, W.; Sun, H. Geraniol and lupeol inhibit growth and promote apoptosis in human hepatocarcinoma cells through the MAPK signaling pathway. J. Cell. Biochem. 2018, 120, 5033-5041, doi:10.1002/jcb.27779.

137. Kuzu, B.; Cüce, G.; Çınar Ayan, İ.; Gültekin, B.; Tuba Canbaz, H.; Gül Dursun, H.; Şahin, Z.; Keskin, İ.; Serpil Kalkan, S.; Kuzu, ul; et al. Evaluation of Apoptosis Pathway of Geraniol on Ishikawa Cells. Nutr. Cancer. 2020, doi:10.1080/01635581.2020.1836244.

138. Shanmugapriya, S.; Subramanian, P.; Kanimozhi, S. Geraniol Inhibits Endometrial Carcinoma via Downregulating Oncogenes and Upregulating Tumour Suppressor Genes. Indian J. Clin. Biochem. 2017, 32, 214219, doi:10.1007/s12291-016-0601-x.

139. Cho, M.; So, I.; Chun, J.N.; Jeon, J.H. The antitumor effects of geraniol: Modulation of cancer hallmark pathways (Review). Int. J. Oncol. 2016, 48, 1772-1782, doi:10.3892/ijo.2016.3427.

140. Hajizadeh, M.; Maleki, H.; Barani, M.; Fahmindehkar, M.A.; Mahmoodi, M.; Torkzadeh-Mahani, M. In vitro cytotoxicity assay of D-limonene niosomes: an efficient nano-carrier for enhancing solubility of plant-extracted agents. Res. Pharma. Sci. 2019, 14, 448.

141. Ye, Z.; Liang, Z.; Mi, Q.; Guo, Y. Limonene terpenoid obstructs human bladder cancer cell (T24 cell line) growth by inducing cellular apoptosis, caspase activation, G2/M phase cell cycle arrest and stops cancer metastasis. $J$. BUON. /Off. J. Balk. Union. Oncol. 2020, 25, 280-285.

142. Rajendran, J.; Pachaiappan, P.; Thangarasu, R. Citronellol, an Acyclic Monoterpene Induces MitochondrialMediated Apoptosis through Activation of Proapoptotic Factors in MCF-7 and MDA-MB-231 Human Mammary Tumor Cells. Nutr. Cancer. 2020, 1-11, doi:10.1080/01635581.2020.1800766.

143. Cavalieri, E.; Mariotto, S.; Fabrizi, C.; de Prati, A.C.; Gottardo, R.; Leone,S.; Berra, L.V.; Lauro, G.M.; Ciampa, A.R.; Suzuki, H. $\alpha$-Bisabolol, a nontoxic natural compound, strongly induces apoptosis in glioma cells. Biochem. Biophys. Res. Commun. 2004, 315, 589-594.

144. Rigo, A.; Ferrarini, I.; Lorenzetto, E.; Darra, E.; Liparulo, I.; Bergamini, C.; Sissa, C.; Cavalieri, E.; Vinante, F. BID and the $\alpha$-bisabolol-triggered cell death program: Converging on mitochondria and lysosomes. Cell. Death Dis. 2019, 10, 1-13.

145. Billen, L.P.; Kokoski, C.L.; Lovell, J.F.; Leber, B.; Andrews, D.W. Bcl-XL inhibits membrane permeabilization by competing with Bax. PLoS Biol. 2008, 6, 1268-1280, doi:10.1371/journal.pbio.0060147.

146. Viktorová, J.; Stupák, M.; Kateřinařehořová, K.K.; Dobiasová, S.; Hoang, L.; Hajšlová, J.; Thanh, T. Van; Tri, L. Van; Tuan, N. Van; Ruml, T. Lemon Grass Essential Oil does not Modulate Cancer Cells Multidrug Resistance by Citral-Its Dominant and Strongly Antimicrobial Compound. Foods, 2020, 9, 585, doi:10.3390/foods9050585.

147. Ruvinov, I.; Nguyen, C.; Scaria, B.; ... C.V.-I. cancer; 2019, undefined Lemongrass extract possesses potent anticancer activity against human colon cancers, inhibits tumorigenesis, enhances efficacy of FOLFOX, and reduces its adverse. Intergr. Cancer. Ther. 2019, 18, doi:10.1177/1534735419889150.

148. Yen, N.; Zainah, A.; Arapoc, D.J.; Mohamed, Z.A.M.A.; Shafii, K. Anticancer Effect and Apoptosis Induction of Cymbopogon citratus Plant on Head and Neck HTB43 Cancer Cell Lines. Res. Develop. Sem. 2016.

149. Lima, D.A.N. De; Pelegrini, B.B.; Uechi, F.A.A.; Varago, R.C.; Pimenta, B.B.; Kaneshima, A.M.de S.; Kaneshima, E.N.; Souza, P.da C.; Pedroso, R.B.; Silveira, T.G.V.; Becker, T.C.A. Evaluation of Antineoplasic Activity of Zingiber Officinale Essential Oil in the Colorectal Region of Wistar Rats. Asian Pac. J. Cancer. Prevent. 2020, 21, 2141.

150. Poltronieri, P.; Xu, B.; Giovinazzo, G. Resveratrol and other Stilbenes: Effects on Dysregulated Gene Expression in Cancers and Novel Delivery Systems. Anti Cancer. Agent. Med. Chem. 2020, 21, 567-574.

151. Farooqi, A.A.; Fayyaz, S.; Poltronieri, P.; Calin, G.; Mallardo, M. Epigenetic deregulation in cancer: Enzyme players and non-coding RNAs. Semin. Cancer Biol. 2020, Ahead of print, doi:10.1016/j.semcancer.2020.07.013.

152. Yeoung Lee, H.; Wan Son, S.; Moeng, S.; Young Choi, S.; Kook Park, J. The role of noncoding RNAs in the regulation of anoikis and anchorage-independent growth in cancer. Int. J. Mol. Sci 2021, 22, 627, doi:10.3390/ijms22020627.

153. Xu, Q.; Li, M.; Yang, M.; Yang, J.; Xie, J.; Lu, X.; Wang, F.; Chen, W. $\alpha$-pinene regulates miR-221 and induces G2/M phase cell cycle arrest in human hepatocellular carcinoma cells. Bio. Rep. 2018, 38.

154. Farooqi, A.A.; Fuentes-Mattei, E.; Fayyaz, S.; raj, P.; Goblirsch, M.; Poltronieri, P.; Calin, G.A. Interplay between 
epigenetic abnormalities and deregulated expression of microRNAs in cancer. Semin. Cancer Biol. 2019, 58, 47-55.

155. Goyal, R.; Bhat, S.; Kamath, S.; Aggarwall, M.; Bhandarkar, M.; Mahima, B.; Sukreeth, S. A novel anti-oxidant lemongrass oil mouthwash-a clinical trial. J. Exp. Biol. Sci. 2011, 2.

156. Kim, I.; Oh, Y.A.; Lee, H.; Song, K.B.; Min, S.C. Grape berry coatings of lemongrass oil-incorporating nanoemulsion. LWT-Food Sci. Technol. 2014, 58, 1-10.

157. Tchoumbougnang, F.; Amvam Zollo, P.H.; Dagne, E.; Mekonnen, Y. In vivo antimalarial activity of essential oils from Cymbopogon citratus and Ocimum gratissimum on mice infected with Plasmodium berghei. Planta Med. 2005, 71, 20-23, doi:10.1055/s-2005-837745.

158. Ntonga, P.; Baldovini, N.; Mouray, E.; Mambu, L.; Belong, P.; Grellier, P. Activity of Ocimum basilicum, Ocimum canum, and Cymbopogon citratus essential oils against Plasmodium falciparum and mature-stage larvae of Anopheles funestus ss. Parasite. 2014, 21.

159. Oladeji, O.S.; Adelowo, F.E.; Ayodele, D.T.; Odelade, K. A. Phytochemistry and pharmacological activities of Cymbopogon citratus: A review. Sci. African 2019, 6.

160. Solomon, B.; Gebre-Mariam, T.; Asres, K. Mosquito repellent actions of the essential oils of Cymbopogon citratus, Cymbopogon nardus and Eucalyptus citriodora: Evaluation and formulation studies. J. Essent. Oil-Bearing Plants. 2012, 15, 766-773, doi:10.1080/0972060X.2012.10644118.

161. Eden, W.T.; Alighiri, D.; Supardi, K.I.; Cahyono, E. The Mosquito Repellent Activity of the Active Component of Air Freshener Gel from Java Citronella Oil (Cymbopogon winterianus). J. Parasitol. Res. 2020, doi:10.1155/2020/9053741.

162. Tak, J.; Isman, M. Metabolism of citral, the major constituent of lemongrass oil, in the cabbage looper, Trichoplusia ni, and effects of enzyme inhibitors on toxicity and metabolism. Pestic. Biochem. Physiol. 2016, 133, 20-25.

163. Jovanović, J.; Krnjajić, S.; Ćirković, J.; Radojkovic, A.; Popovic, T.; Brankovic, G.; Brankovic, Z. Effect of encapsulated lemongrass (Cymbopogon citratus L.) essential oil against potato tuber moth Phthorimaea operculella. Crop Prot. 2020, 132, 105109.

164. Plata-Rueda, A.; Rolim, G.D.S.; Wilcken, C.F.; Zanuncio, J.C.; Serrão, J.E.; Martínez, L.C. Acute Toxicity and Sublethal Effects of Lemongrass Essential Oil and Their Components against the Granary Weevil, Sitophilus granarius. Insects. 2020, 11, 379, doi:10.3390/insects11060379.

165. Manh, H.D.; Hue, D.T.; Hieu, N.T.T.; Tuyen, D.T.T.; Tuyet, O.T. The mosquito larvicidal activity of essential oils from Cymbopogon and Eucalyptus species in vietnam. Insects. 2020, 11, 1-7, doi:10.3390/insects11020128.

166. Feroz, A. Efficacy and cytotoxic potential of deltamethrin, essential oils of Cymbopogon citratus and Cinnamonum camphora and their synergistic combinations against stored product pest, Trogoderma granarium (Everts). J. Stored Prod. Res. 2020, 87, 101614, doi:10.1016/j.jspr.2020.101614.

167. El Mokhtari, K.; EL Kouali, M.; Talbi, M.; Hajji, L.; El Brouzi, A. Chemical composition and insecticidal activity of Anacyclus pyrethrum essential oil from the Bensliman area against Culex pipiens. Mediterr. J. Chem. 2020, 10, 1321, doi:10.13171/mjc101020211198kem.

168. Afify, A.; Betz, J.F.; Riabinina, O.; Lahondère, C.; Potter, C.J. Commonly Used Insect Repellents Hide Human Odors from Anopheles Mosquitoes. Curr. Biol. 2019, 29, 3669-3680, doi:10.1016/j.cub.2019.09.007.

169. Aboelhadid, S.M.; Youssef, I.M.I. Control of red flour beetle (Tribolium castaneum) in feeds and commercial poultry diets via using a blend of clove and lemongrass extracts. Environ. Sci. Pollut. Res. 2021, 1-10, doi:10.1007/s11356-021-12426-7.

170. Cherng, J.M.; Shieh, D.E.; Chiang, W.; Chang, M.Y.; Chiang, L.C. Chemopreventive effects of minor dietary constituents in common foods on human cancer cells. Biosci. Biotechnol. Biochem. 2007, 71, 1500-4.

171. Nordin, N.; Yeap, S.K.; Zamberi, N.R.; Abu, N.; Mohamad N.E.; Rahman, H.S.; How, C.W.; Masarudin, M. J.; Abdullah, R.; Aitheen, N.B. Characterization and toxicity of citral incorporated with nanostructured lipid carrier. PeerJ. 2018, 6, 3916.

172. Philion, C.; Ma, D.; Ruvinov, I.; Mansour, F.; Pignanelli, C.; Noel, M.; Saleem, A.; Arnason, J.; Rodrigues, M.; Singh, I.; Ropat, J.; Pandey S. Cymbopogon citratus and Camellia sinensis extracts selectively induce apoptosis in cancer cells and reduce growth of lymphoma xenografts in vivo. Oncotarget, 2017, 8, 110756-110773. doi: 10.18632/oncotarget.22502 